\title{
Neural correlates of fairness consideration in children in interaction with their In-/Out-group: An event-related potential study
}

\author{
Fatemeh Keshvari ${ }^{1 *}$ (D), Hossein Lotfabadi ${ }^{2}$, Saeed Imani ${ }^{3}$, Mojtaba Habibi ${ }^{4}$ \\ 1. PhD Student in Cognitive Psychology, Institute for Cognitive and Brain Sciences, Shahid Beheshti University, Tehran, Iran \\ 2. Professor of Psychology, Department of Clinical and Health Psychology, Shahid Beheshti University, Tehran, Iran \\ 3. Assistant Professor of Clinical Psychology, Department of Clinical and Health Psychology, Shahid Beheshti University, Tehran, Iran \\ 4. Assistant Professor of Health Psychology, Department of Health Psychology, School of Behavioral Sciences and Mental Health (Teh- \\ ran Institute of Psychiatry), Iran University of Medical Sciences, Tehran, Iran
}

Recieved: 26 Nov. 2018

Revised: 31 Dec. 2018

Accepted: 15 Jan. 2019

Keywords

Fairness

Disadvantageous inequality aversion Advantageous inequality aversion Group membership

Feedback related negativity (FRN)

\section{Corresponding author}

Fatemeh Keshvari, PhD Student in Cognitive Psychology, Institute for Cognitive and Brain Sciences, Shahid Beheshti University, Tehran, Iran

Email: Fatemehkeshvari@yahoo.com

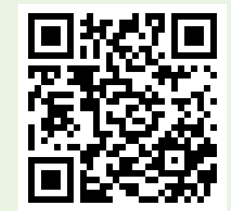

doi.org/10.30699/icss.21.3.1

\section{Abstract}

Introduction: The avoidance of inequality means that individuals like to ignore some of their capital not to receive less or more than their social partners. This variable is a key factor in establishing fairness. The present study aimed to investigate the neural correlates of inequality avoidance and the effect of group membership on this behavior among 6-year-old children

Methods: The population of this research included healthy 6-year-old children from Tehran in 2018-2019. Hence, 15 children (4 girls and 11 boys) residing in Tehran were selected. In the ultimatum game, the children were presented by (un)fair offers from either in-group or out-group members. Also, in order to record brain waves' data 32-channel EEG8 device were used.

Results: The results showed that the children accepted significantly equal offers than advantageous and disadvantageous inequal offers $(\mathrm{P}=0.001)$ and offers presented by their in-group members than out-group members $(\mathrm{P}=0.041)$. Besides, the FRN wavelength in response to unfair offers was more than fair offers; this effect was observed in connection with the offers presented by their in-group members. Morover, the P-300 amplitude in exposure to equal and advantagous inequal offers was more when they were opposed from their in-group members.

Conclusion: The results attained in this study are indicative of the fact that early emotional and cognitive late brain waves in response to perceived equality and inequality are identified by children.

Citation: Keshvari F, Lotfabadi H, Imani S, Habibi M. Neural correlates of fairness consideration in children in interaction with their In-/Out-group: An event-related potential study. Advances in Cognitive Sciences. 2019;21(3):1-17. 


\title{
همبستهاى عصبشناختى عدالت در كودكان در تعامل با تروه خودى/غيرخودى: يك مطالعه يتانسيل وابسته به رويداد
}

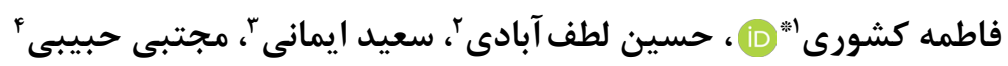

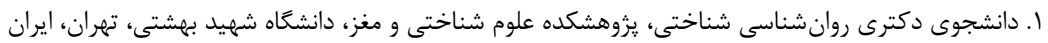

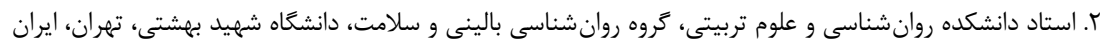

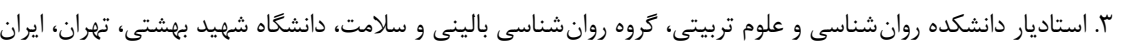

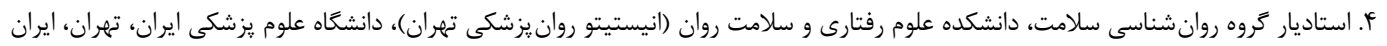

\section{ars}

مقلهمه: اجتناب از نابرابرى به معناى تمايل به كذشتن از مقدارى از سرمايه به جهت دريافت نكردن كمتر يا بيشتر از شريك اجتماعى است. اين مؤلفه عامل كليدى در برقرارى عدالت است. مطالعه حاضر با هدف بررسى همبستهاى عصبشناختى اجتناب از نابرابرى و اثر عضويت كروهى بر اين رفتار در كودكان 9 ساله انجام گرفت.

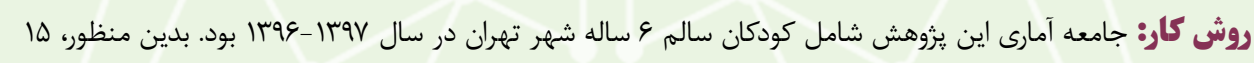
كودى (f دختر، 11 يُر) ساكن شهر تهران در اين مطالعه شركت كردند. در تكليف اولتيماتوم، يِيشنهادهاى برابر/ابرابر از سوى افراد كروه خودى و غيرخودى به كودكان شركت كننده ارائه شد. ثبت دادههاى امواج مغزى نيز از طريق دستخاه

$$
\text { EEG8 }
$$

يافته ها: يافتهها نشان داد كه كودكان به طور معنادارى پيشنهادهاى برابر را بيشتر از بيشنهادهاى نابرابر سودمند و

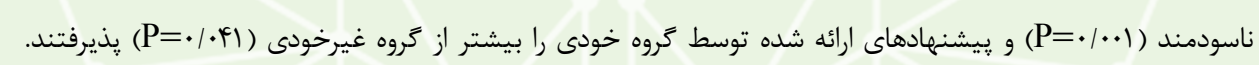
همجنين طول موج FRN در پاسخ به بيشنهادهاى نابرابر بيشتر از پيشنهادهاى برابر بود، اين اثر در رابطه با پيشننهادهاى ارائه شده توسط گروه خودى نيز مشاهده شد. علاوه بر اين طول موج P300 در مواجهه با پِيشنهادهاى برابر و نابرابر

$$
\text { سودمند از سوى گروه خودى بيشتر بود. }
$$

نتيجه گَيرى: از يافته هاى مطالعه حاضر مى توان اين كونه نتيجه كَيرى كرد كه امواج مغزى زودهنگًام هيجانى و ديرهنحام شناختى در پاسخ به بىعدالتى و عدالت ادارك شده توسط كودكان قابل شناسايى است.
\end{abstract}

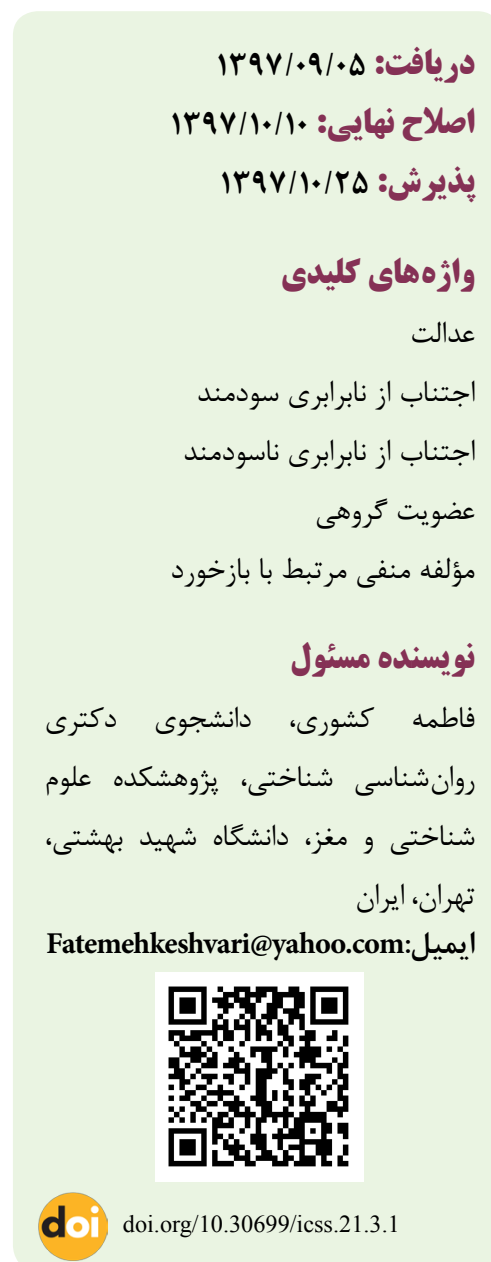

هolä

كودكان خردسال وقتى كه بنا بود ميزان نابرابرى از منابع را به هر يك

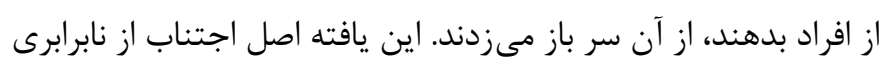

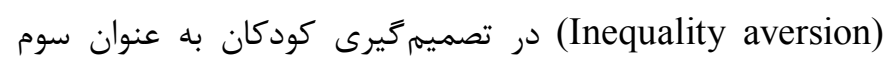
شخص را مطرح كرد (1). اما در رابطه با اينكه كودى خود نيز گيرنده منابع باشد، بيان شده است كه در حدود بأب سالكى كودكان معنى
از سنين كودكى، افراد عدالت و برابرى را در رفتارهاى اجتماعى خود و ديخران در نظر مى گيرند. يكى از راههاى بررسى عدالت، مطالعه رفتار افراد در تكاليف تخصيص منابع يا به اشتراك گذارى است. در مطالعه

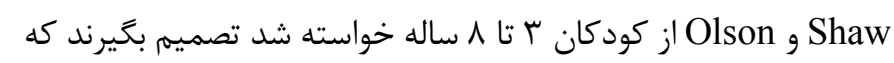
منابع جُخونه بين دو فرد ناشناس ديخر تقسيم شود. مشخص شد حتى 
از نابرابرى ناسودمند ممكن است ريشه تكاملى داشته باشد، در حالى كه اجتناب از نابرابرى سودمند به عواملى كه در كونه انسان وجود دارد بستخى دارد. Blake و همكاران در مطالعه اجتناب از نابرابرى سودمند و ناسودمند

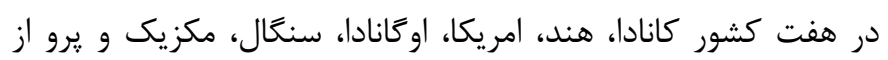

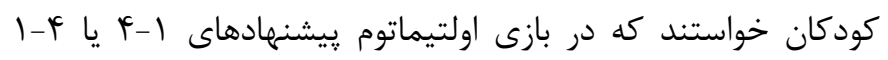

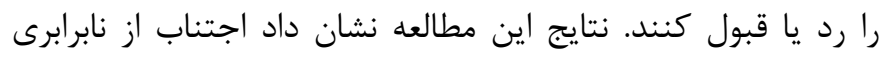

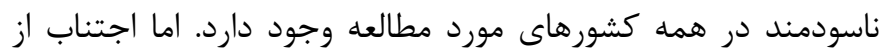
نابرابرى سودمند تنها در سه كشور كانادا، امريكا و اوكاندا مشاهده

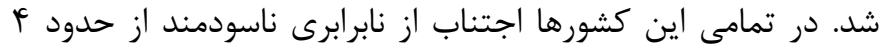

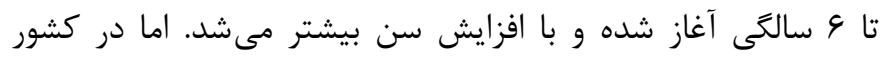

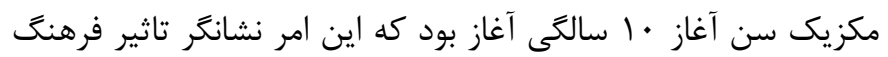

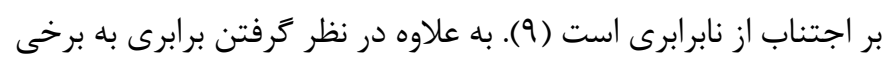

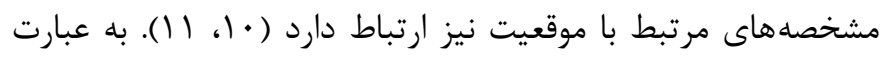

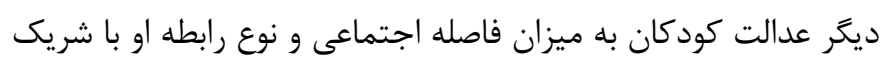

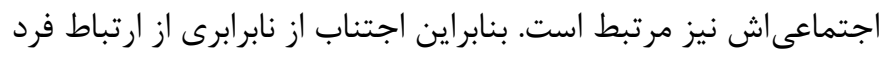

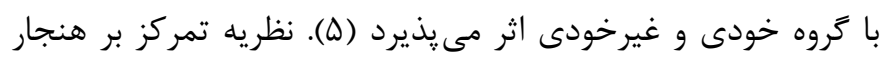

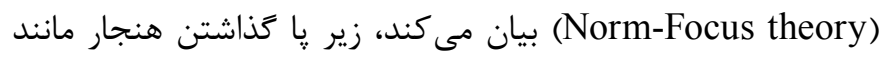

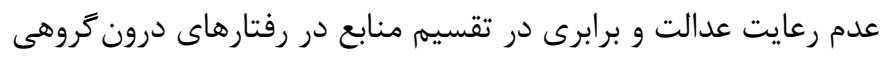
به شدت نكوهيده بر شمرده مىشوند. بر طبق اين نظريه، افراد، انتظار

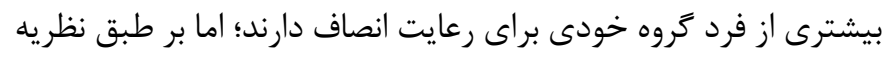

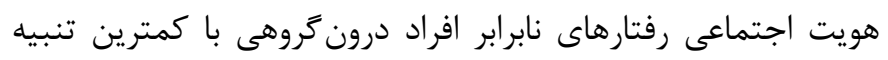

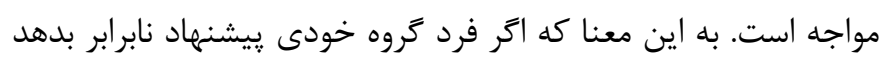

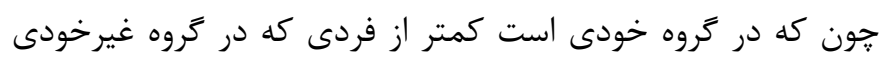

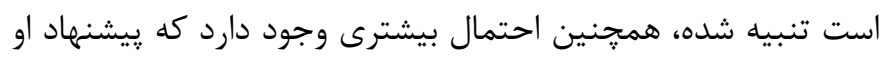

مورد يذيرش قرار بخيرد (r ( ). مطالعات عصبشناختى نواحى مختلف مغزى درگير در مقايسه خود و ديخرى را به هنخام انجام بازى اولتيماتوم شناسايى كردهاند. برابرى و عدالت با نواحى مغزى مرتبط با عاطفه مثبت و منفى كه شامل

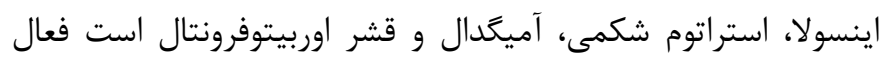

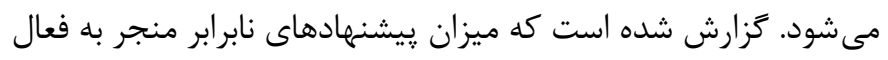

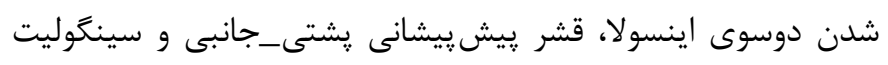

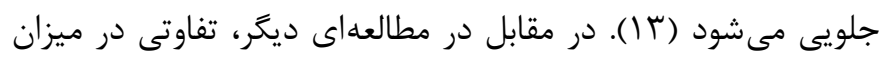

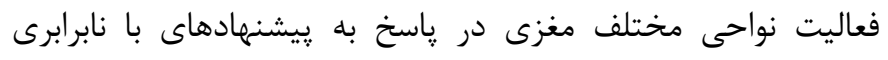

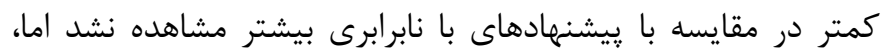

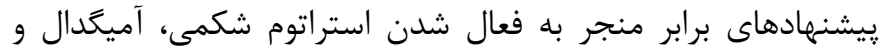

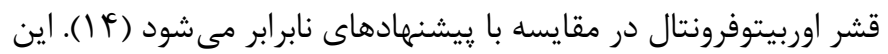

هنجار برابرى (Fairness) را مى دانند، اما در حدود V-^ سالكى رفتار

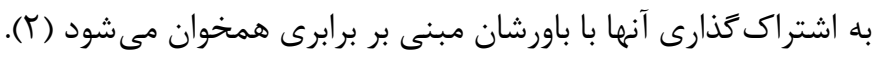

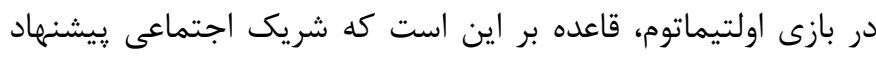

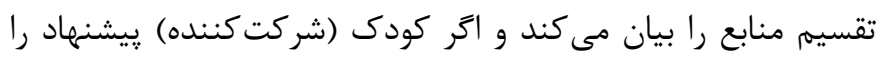

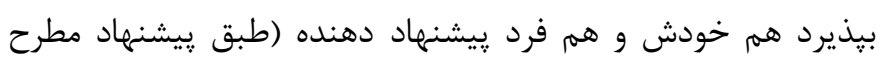

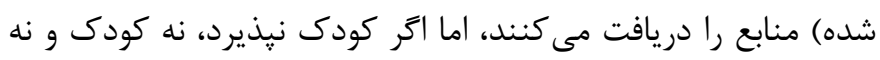

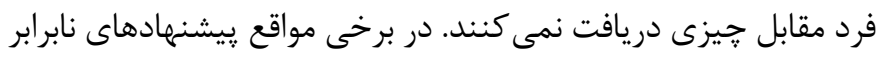

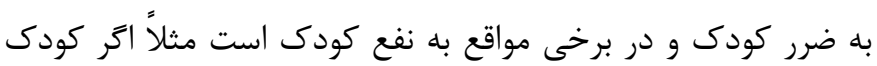

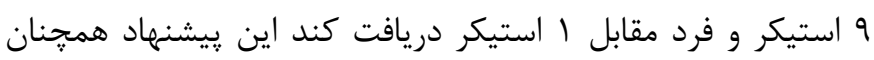

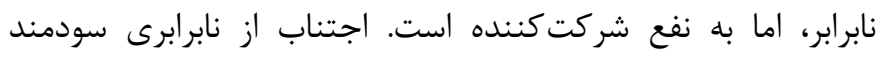

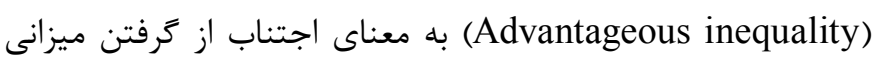

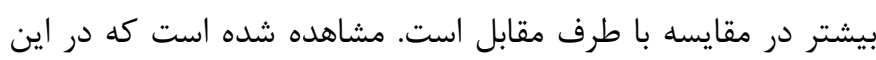

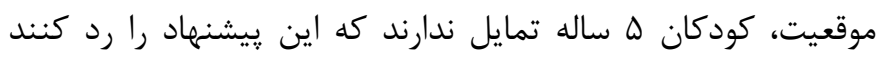
(با). در عوض، اجتناب از نابرابرى ناسودمند (بsadvantageous) (inequality

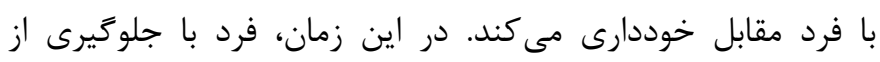

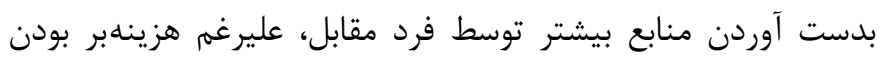
اعلام مى كند كه حاضر نيست مورد بهره كشى قرار گيرد، ولى بـ به دئ دنبال

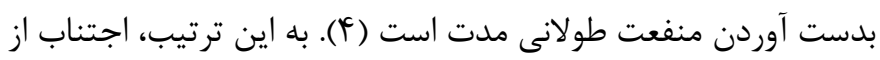

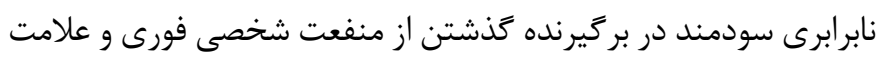

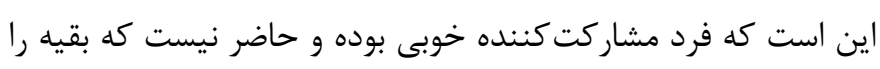

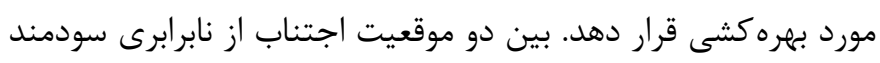

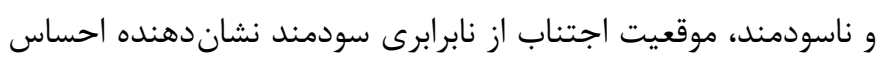
برابرى قوى ترى است. Fehr و بر اين باورند كه هر دو نوع اجتناب از نابرابرى در إس

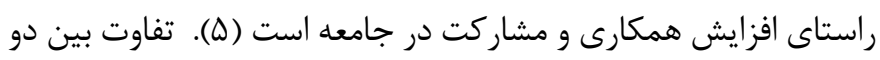

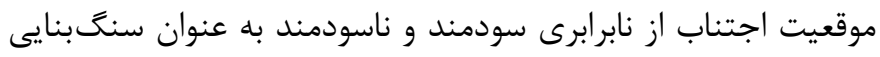

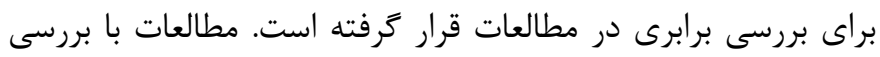

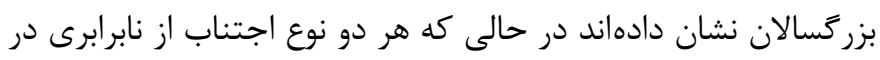

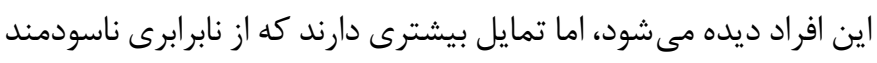

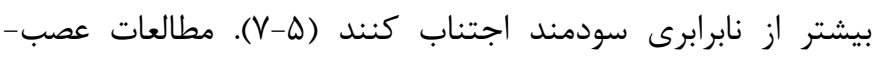

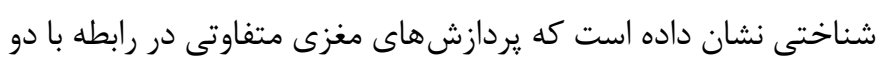

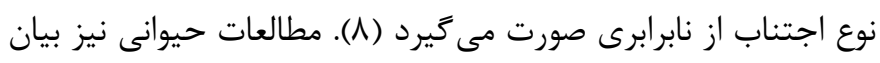

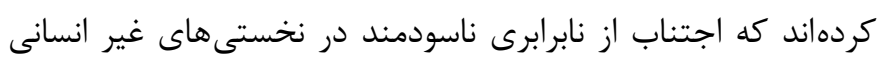
و ساير تونهها وجود دارد، در حالى كه دهاى (Non-human primates)

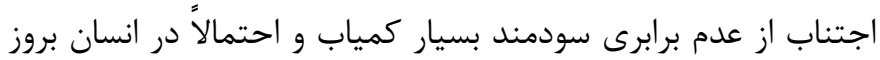

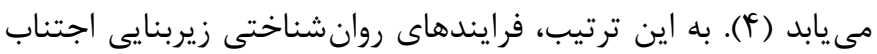


شده توسط دوست و غريبه دريافتند كه بلندى موج FRN در ياسخ به ييشنهادهاى نابرابر بيشتر بوده، طول اين موج از رابطه اجتماعى بين كيرنده و ي يشنههاد دهنده نيز اثر مى يذيرد (9 (). بدين ترتيب، طول موج دRN ييشنهاد توسط افراد غريبه بود. همجنين آنها نشان دادند موج FRN در پيشنهادهاى نابرابر دوست بيشتر از ي يشنهرادهاى برابر بوده است. اما اين مورد در رابطه با ييشنهادهاى فرد غريبه مشاهده نشده است. موج ديرهنگام P300 به هنَام ارزيابى شناختى از عدالت طول بيشترى را نشان مى دهد. به علاوه، يزوهشهاى اندكى نشان دادهاند كه موج P300 از نشانههاى اجتماعى مانند مشاهده دوستانى كه پياداش

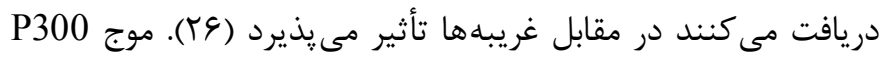
در فرايندهايى مانند تخصيص توجه (آ⿱)، ارزيابى انخيزش/عاطفه بالا P300 بررسى شده و محققان بر اين عقيده بودهاند كه موج (YT) بزرختر در شرايط مشاهده دوست ممكن است باعث افزايش درگيرى فرايندهاى توجهى اعاطفى باشد. به اين ترتيب، مى توان ريشبيشى كرد كه در تكليف تخصيص منابع، در مواجهه با فرد هم گروه افزايش موج

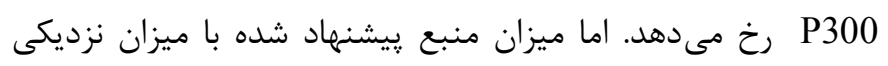
فرد با شركت كننده در شرايط نابرابر متعارض است. در مطالعه و همكاران مشخص شدكه طول موج P300 در رابطه با ييشنهادهاى برابر بيشتر از ييشنهادهاى نابرابر بود. اما آنها ارتباطى بين ييشنهادهاى ارائه شده توسط دوست و غريبه و طول موج P300 نيافتند (19). يزوهش ديخرى نشان داد رد ييشنهادهاى نابرابر توسط فرد زروه خودى در بزركسالان از نظريه تمركز بر هنجار تبعيت كرده و افراد فرد درون ₹روهى را با رد ييشنهاد نابرابر تنبيه مى كنند ( • (؟). در حاليكه بررسى همبستههاى عصبى سودرسانى اجتماعى در كودكان كه همجنان اندى باقيمانده است (Yr)، مطالعه حاضر به بررسى لرى عدالت در موقعيت هاى نابرابر سودمند و ناسودمند و همجنين، نقش عضويت گروهى در اجتناب از نابرابرى كودكان يرداخته است. در مطالعه حاضر انتظار مىرفت طول موج FRN در پيشنهادهاى نابرابر بيشتر از ييشنهادهاى برابر و طول موج P300 در ريشنهادهاى برابر

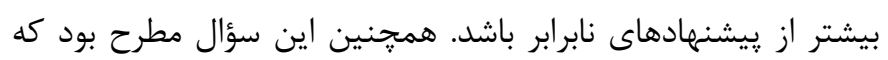
آيا ييشنهادهاى ارائه شده توسط فرد گروه خودى و غيرخودى بر طول امواج FRN و P300 اثر كذار است؟

\section{روش كار}

جامعه آمارى اين يزوهش شامل كودكان سالم 9 ساله شهر تهران در

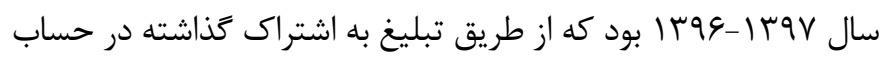

نشانگر اين است كه برابرى، محرك اجتماعى گپاداش دهنده است. به علاوه، افراد به هنگَام دريافت ييشنهادهاى برابر عاطفه مثبت بيشترى

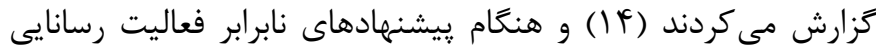
يوستى بيشتر از ييشنهادهاى برابر بوده است (ه (1).

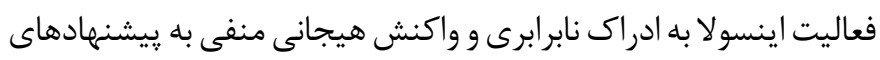
نابرابر همبسته است. همجنين اينسولا به هنگام بروز خطا در ارتباط با لهاب تخطى از هنجار (ييشنهاد نابرابر) نيز فعال مىشود (ع) (1). مرحله اول در فرايند تصميهميرى شامل ارزيابى حالات درونى (هنجار برابرى يا اهداف خود محور) و بيرونى (اطلاعات مرتبط با بافت مانند قصد) است. هيجان منفى با تصميم گيرى مرتبط با نابرابرى به همراه سيخنال خطا (اختلاف بين انتظار برابرى و زيشنهادهاى نابرابر) مرتبط بوده و اين نشان گر آن است كه افراد رفتارهايى انجام مى دهند (رد ييشنهاد نابرابر) كه در راستاى هنجار (با تنبيه كردن پيشنههاد دهنده به دليل نابرابرى) يا حالت درونى (حالت هيجانى منفى) باشد (IV) بررسى هاى عصبشناختى ديخر، زَزارش كردهاند امواج مغزى مرتبط با بازخورد (Feédback Related Negativity (FRN) در دامنه زمانى

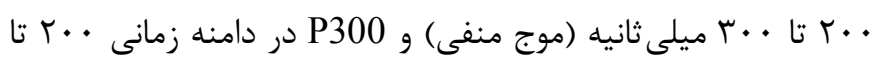

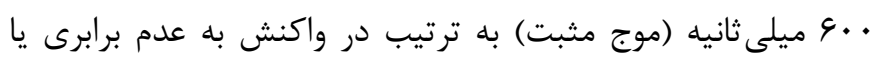
برابرى (1) - (Y)، مواجهه با ييشنهادهاى نابرابر و برابر (9 (1) بروز ييدا مى كنند. مؤلفه FRN كه منبع ايجاد آن ناحيه قشر سينگوليت جلويى

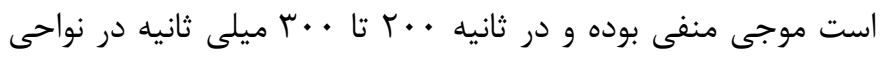
مركزى ييشانى مغز قابل مشاهده است ( (Y-Y) رخداد منفى مرتبط با بيامدهاى غيرقابل انتظار، مانند ياسخ هاى نادرست

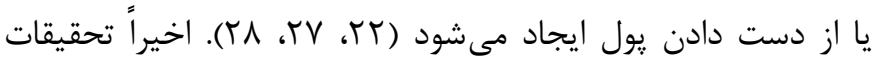
نشان داده است، عدم رعايت هنجارهاى اجتماعى مانند ريشنيهادهاى نابرابر يا نابرابر در تقسيم كردن منابع نيز موجب برانگيختخى موج

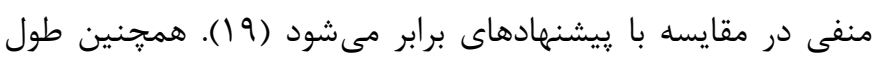
موج FRN با ييشنهاد نابرابر از سوى فرد گروه خودى يا غيرخودى در نمونه بزرگسالان تغيير مى كند (·ץ). مطالعات، نشان دادهاند كه اين تفاوت در واكنش به ييامد تصميم مى تواند از عوامل اجتماعى، مانند

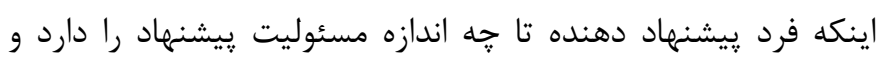

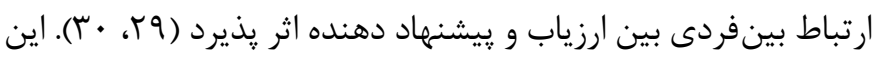
مطالعات بيان مى كنند، مؤلفه FRN ارزيابى انخَيزشى اعاطفى قييامد

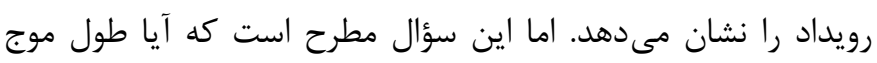
FRN

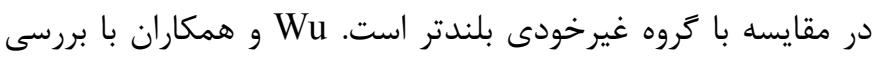
امواج مغزى بزرگسالان در ياسخ به يِيشنهادهاى برابر و نابرابر ارائه 


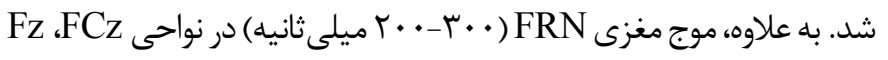

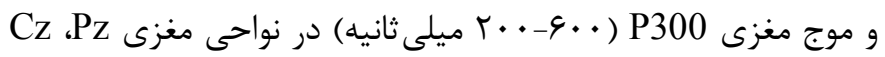
در حين ياسخدهى به تكليف اولتيماتوم با افراد گروه خودى و زروه غيرخودى در آزمونهاى برابر، نابرابر سودمند و نابرابر ناسودمند مورد بررسى قرار گرفت.

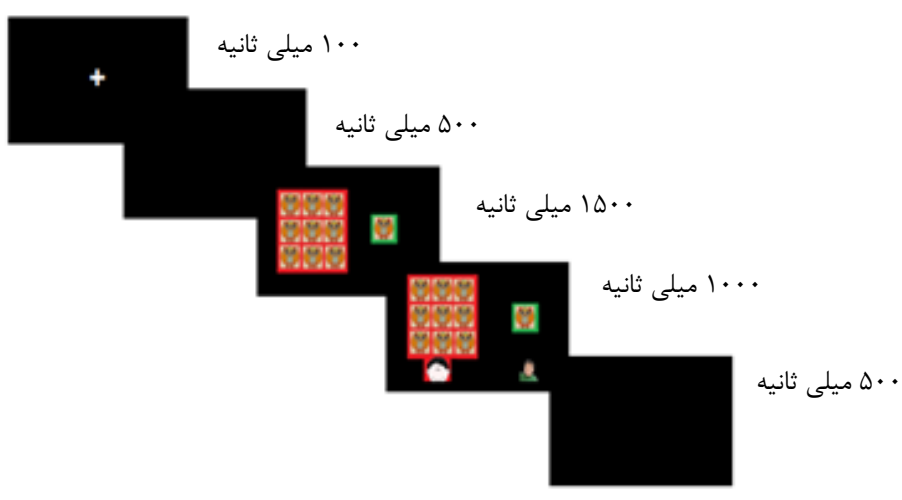

تصوير ا. روند هر آزمون در تكليف اولتيماتوم تعديل شده

روش اجرا: قبل از شروع آزمايش، با استفاده از پارادايم كروه كوجى

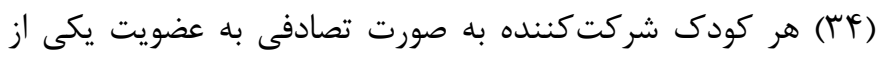

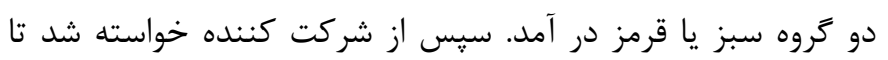

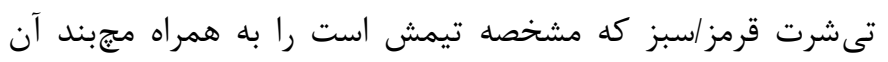

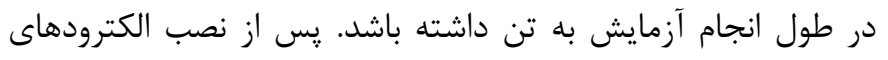

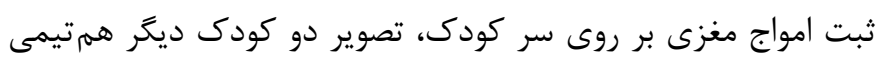

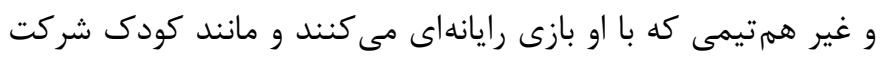

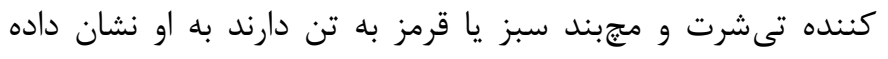

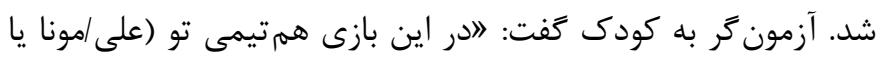

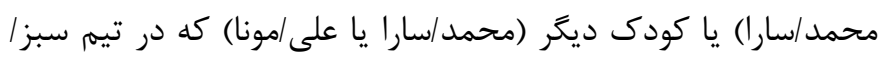
قرمز است تصميم مى گيرند كه تعدادى استيكر را با تو تقسيم كنند.

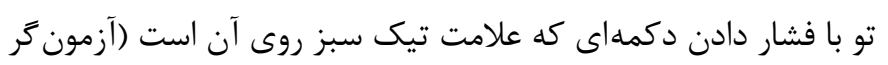

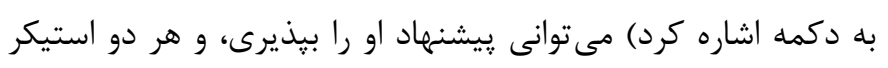

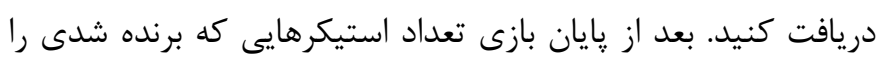

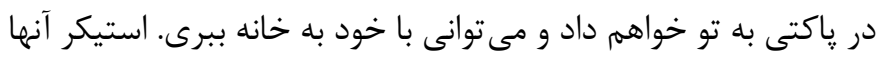

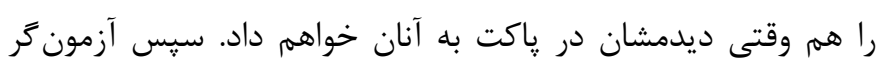

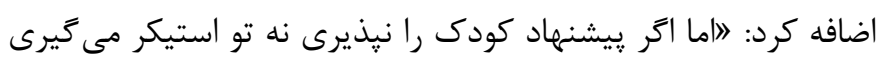

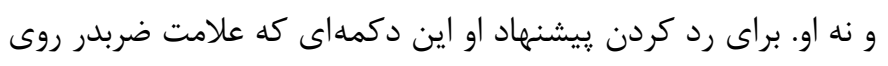

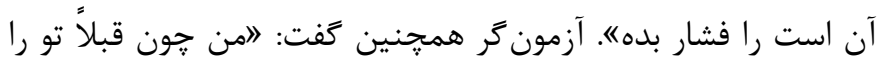

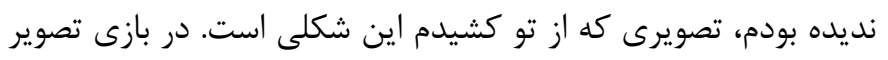

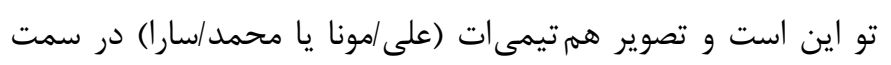

كاربرى مجازى يزوهشكده علوم شناختى و مغز دانشگاه شهيد بهشتى با

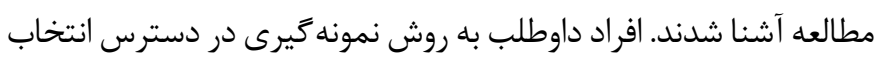

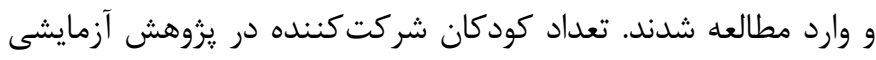

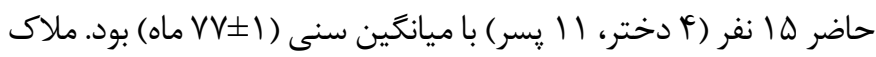

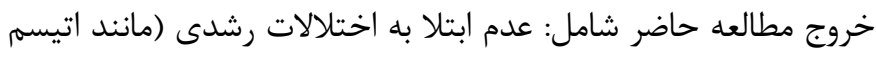

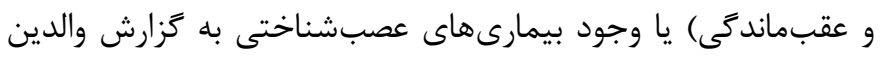

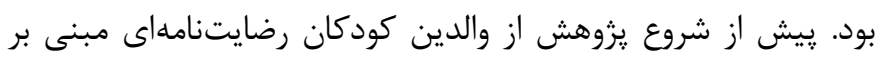

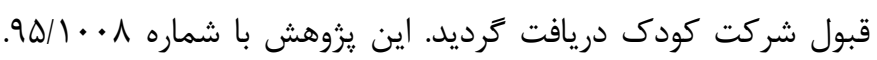

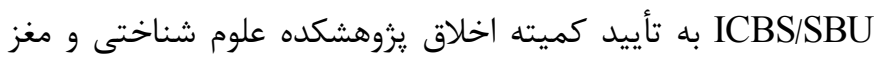
دانشعاه شهيد بهشتى رسيده است. در اين مطالعه از تكليف اولتيماتوم

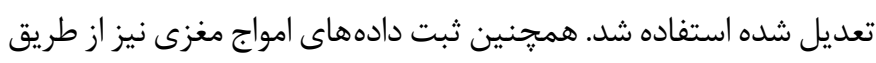
دستخاه EEG8 و كلاه rr كاناله صورت كرفت. تكليف اولتيماتوم تعديل شده (Modified Ultimatum Game): تكليف اولتيماتوم كلاسيك دو بازيكن دارد. بازيكن اول، يُيشنهاد

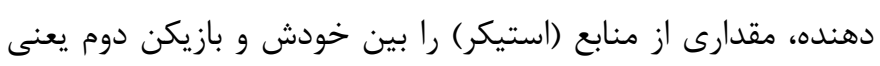

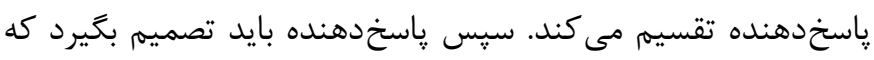

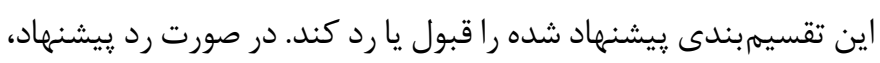

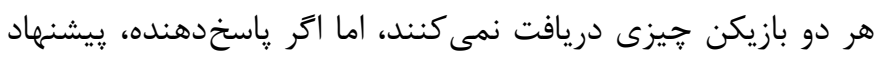

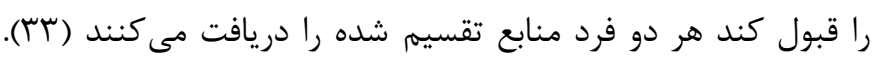

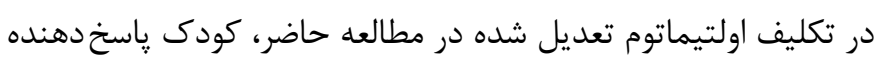

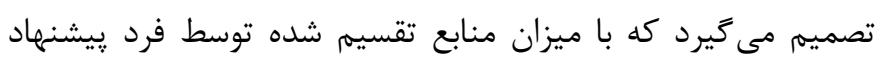

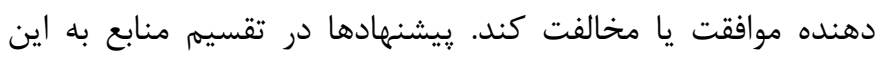

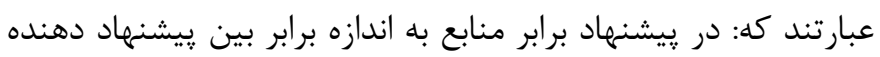

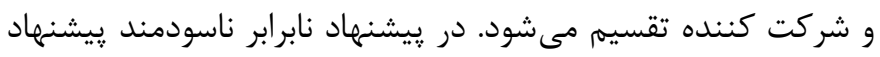
دهنده بيشترين ميزان منابع را براى خودش (9 استيكر) و كمترين

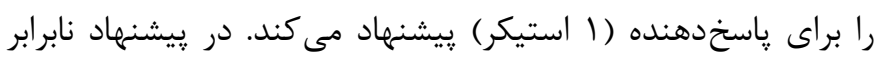

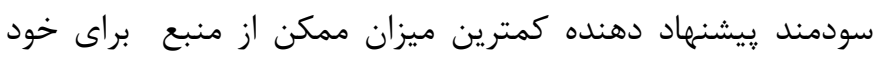

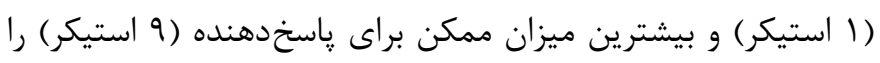

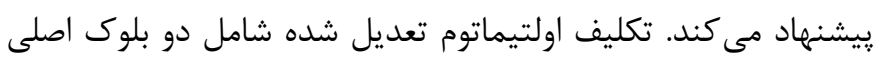

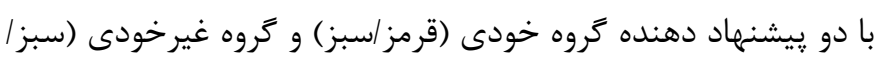

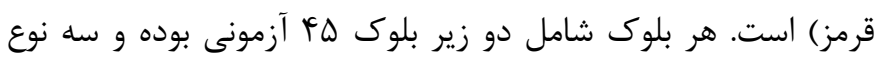

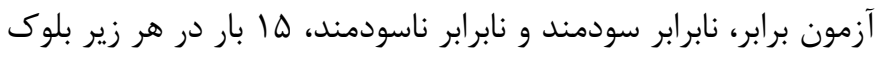

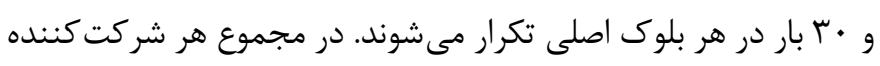

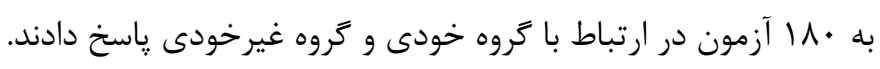

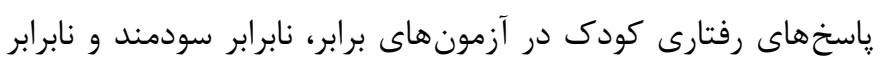

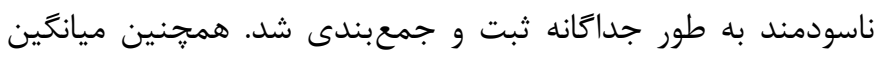

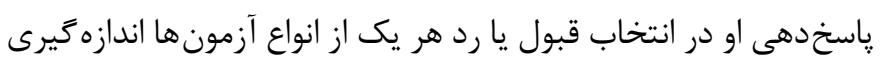


دهندهاى كروه خودى و گروه غير خودى در نواحى كانال هاى مركزى

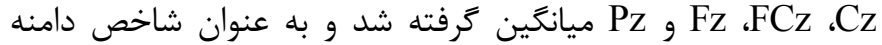
FRN و P300 از هر يك از موقعيتهاى آزمايش يك مؤلفه نهايى

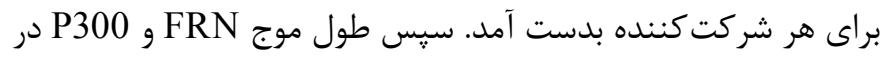
شش موقعيت برابر/Fروه خودى، نابرابر سودمند/گروه خودى و نابرابر ناسودمند/گروه خودى و برابر/آروه غيرخودى، نابرابر سودمند/آروه غيرخودى و نابرابر ناسودمند/گروه غيرخودى براى هر فرد محاسبه و دادها در نرم افزار SPSS-25 تحليل شد.

\section{يافته ها}

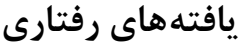

در جدول ا، يافتهاى توصيفى يذيرش انواع بيشنهادهاى برابر،

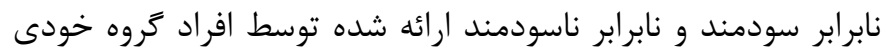

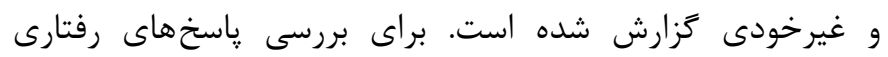

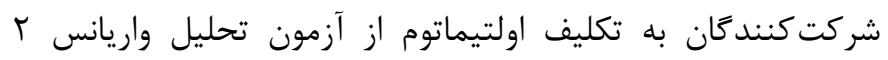

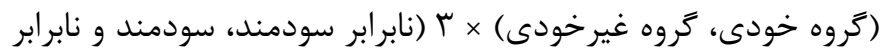
ناسودمند) استفاده شد. متغيرهاى عضويت تروهى و نوع يريشنهاد به عنوان متغير بين آزمودنى مورد بررسى قرار كرفتند. يِيش از آن

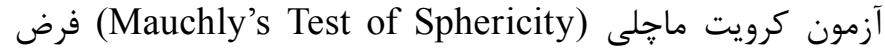
همخنى واريانس را از طريق فرض كرويت تأييد كرد. همجنين آزمون لوين نشان داد كه واريانس بين گروهها در متغير وابسته همكن است.

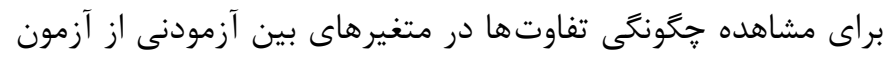
تعقيبى بونفرونى تعديل شده استفاده شد.

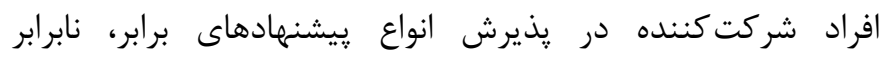

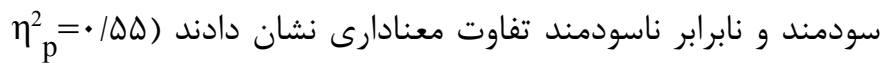

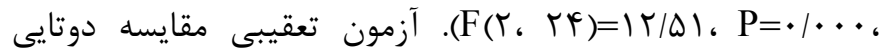

جدول ا. ميانگين و انحراف استاندارد تكليف اولتيماتوم تعديل شده

\begin{tabular}{|c|c|c|}
\hline ميروه غير خودى & ميانگين & \\
\hline$r Y / V Y \pm \varphi$ & $r V / \& \Psi \pm \Delta / T V$ & برابر \\
\hline$r r / r V \pm q / \cdot \Delta$ & $r \Delta / r G \pm \Lambda / q \Lambda$ & نابرابر سودمند \\
\hline$|r / \Lambda| \pm 9 / \Delta F$ & $1 \cdot \pm 9 / 97$ & نابر ابر ناسودمند \\
\hline
\end{tabular}

مقابل استه، در مرحله تمرينى، آزمونگر از كودى مىخواست كه

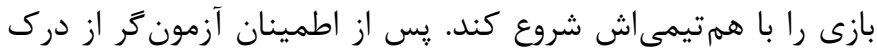

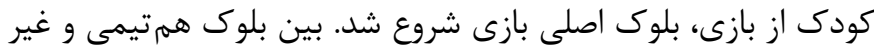

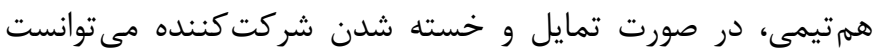

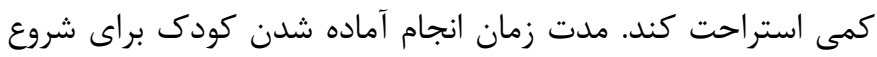
آزمايش حدود هأ دقيقه و زمان مورد نياز براى انجام تكليف تعديل شده اولتيماتوم بين ها - • إ دقيقه بود. ثبت دادهها: امواج مغزى شركت كنندها در حين انجام تكليف اولتيماتوم تعديل شده ثبت شد. دستگاه ثبت امواج مغزى به كار برده شده در مطالعه حاضر از نوع EEG8 ساخت انغليس و كلاه rr كاناله بود. كودكان شركت كننده در مطالعه حاضر با بينايى نرمال يا تصحيح شده و همكى راست دست بودند. سيخنال هاى مغزى با استفاده از

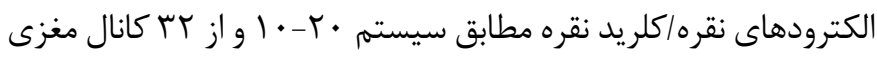

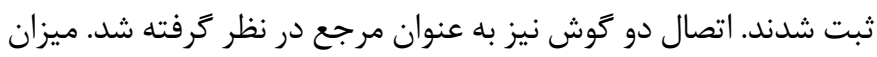

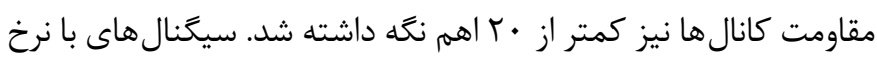
TDS هرتز نمونهبردارى و براى يردازش ذخيره شدند. دادهاى امواج

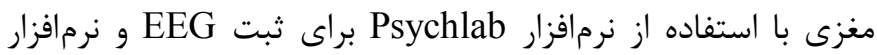

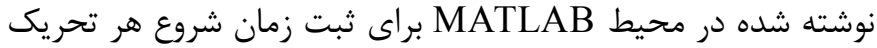
در سيخنال دريافتى EEG ثبت شد تا در يردازش بعدى براى استخراج (Event-related potential (ERP)) ييش يردازش: براى تحليل ERP، ابتدا فركانسهاى زير r و بالاى

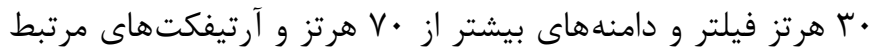

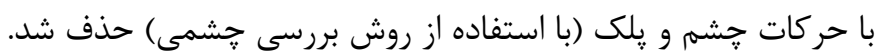

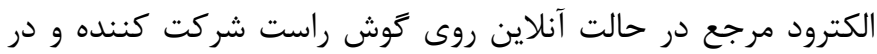

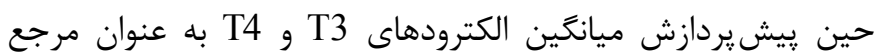
آفلاين در نظر كرفته شد. ايياكهاى (Epoch) مرتبط با هر رويداد (צ رويداد: گروه خودى برابر، گروه خودى نابرابر سودمند، گروه خودى نابرابر ناسودمند، گروه غيرخودى برابر، گروه غيرخودى نابرابر سودمند

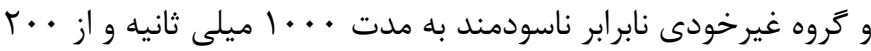
ميلى ثانيه قبل از آغاز رويداد جداسازى شد. در اين مرحله، ايياك هايى ناسيى كه ولتاز بالاتر از .أ ميكرو ولت داشتند نيز حذف شدند. رويدادها

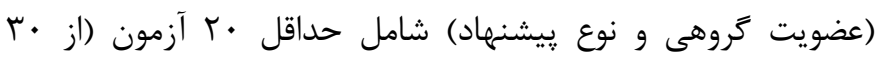
آزمون) بود. در مرحله بِيش يردازش امواج مغزى دو شركت كننده به

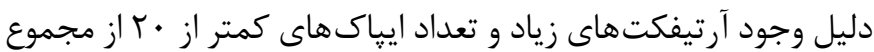

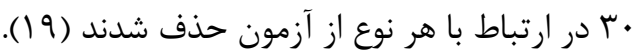

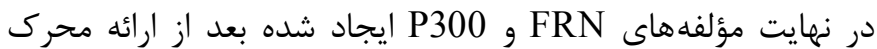
برابر، نابرابر سودمند و نابرابر ناسودمند در ارتباط با هر يك از يريشنهاد 


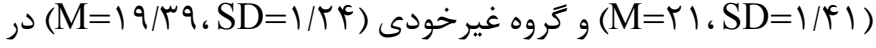
بين افراد شركت كننده تفاوت معنادار وجود داشت. افراد شركت كننده ييشنهادهاى بيشترى از فرد گروه خودى را در مقايسه با فرد كروه غيرخودى يذيرفتند (نمودار ك).

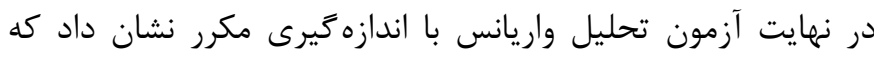

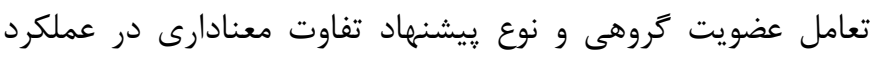
كودكان ايجاد نمى كند (F(T، TF)=1/ه9، P=•/TYA).
نشان داد كه كودكان شركت كننده به طور معنادارى يذيرش كمترى

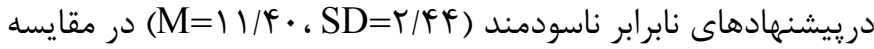

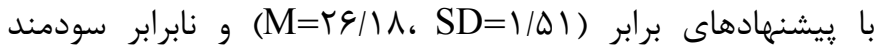

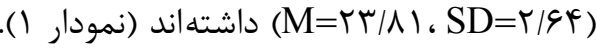

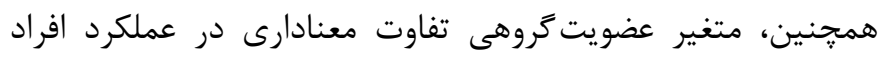

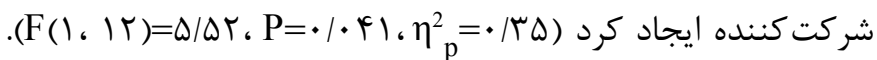
به عبارت ديخر، بين يذيرش انواع بيشنهادها توسط افراد كروه خودى إنى

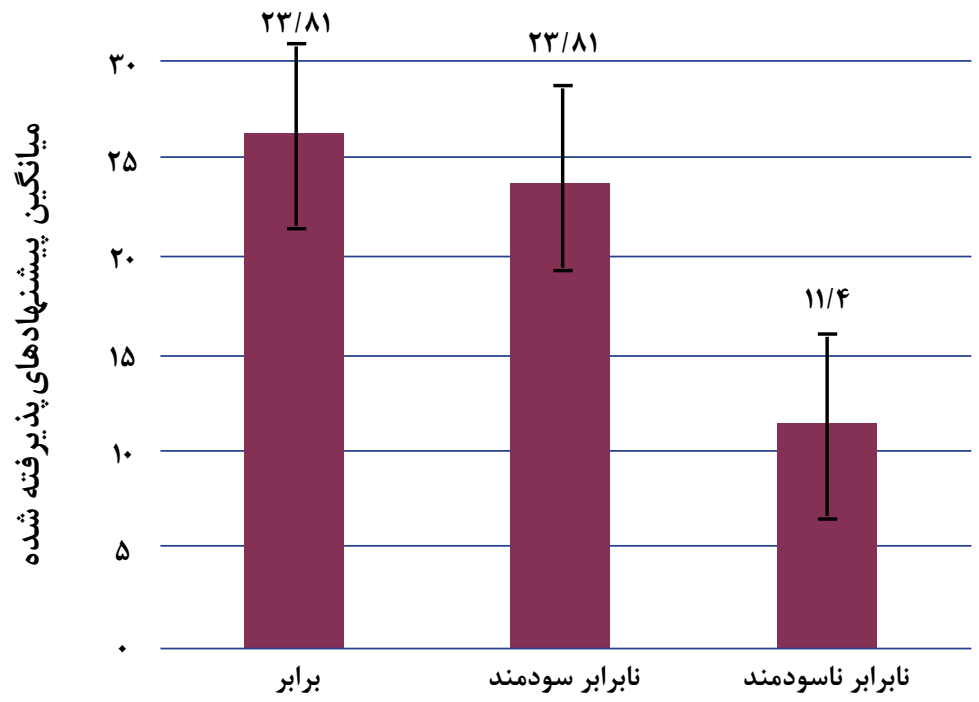

انواع بِيشنهادها

نمودار ا. يذيرش يِشنهادها در تكليف اولتيماتوم به تفكيك انواع پيشنهاد

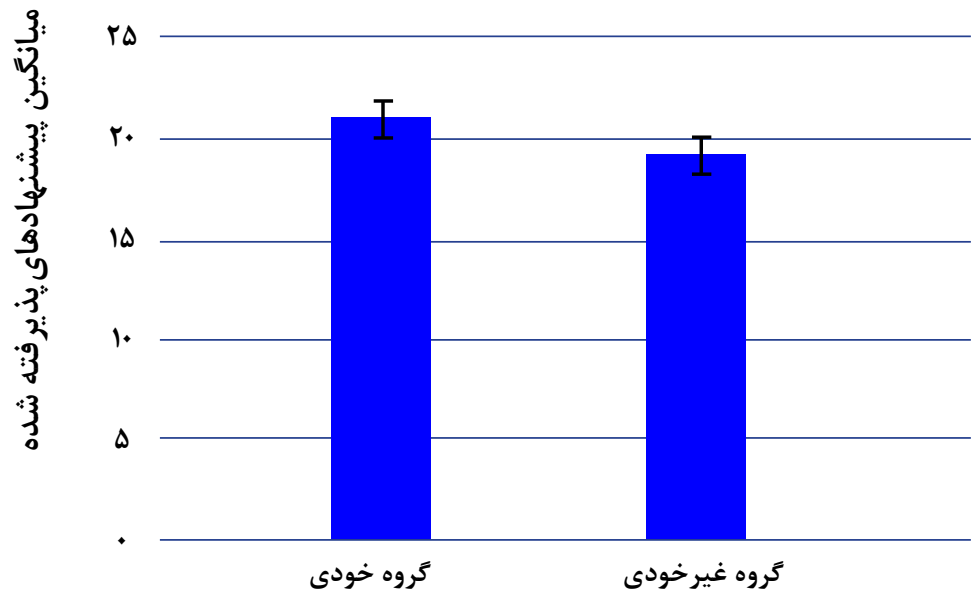

كروه ي ييشنهاد دهنده

نمودار r. يذيرش يِيشنهاد ارائه شده به تفكيك عضويت گروهى 
P300 ايجاد شده متعاقب انواع رخدادها را به تفكيك نوع بيشنهاد و

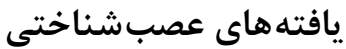

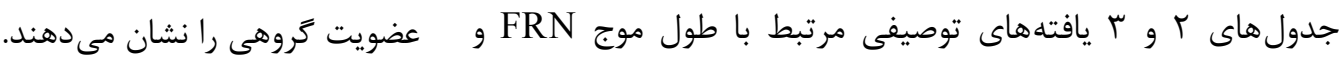

جدول r. ميانگين و انحراف استاندارد طول موج FRN، Fcz در كانال هاى مغزى

\begin{tabular}{|c|c|c|c|c|c|c|c|}
\hline \multicolumn{3}{|c|}{ كروه غيرخودى } & \multicolumn{3}{|c|}{ كروه خودى } & \multirow{2}{*}{ شاخص } & \multirow{2}{*}{ كانال } \\
\hline نابر ابر ناسودمند & نابرابر سودمند & برابر & نابرابر ناسودمند & نابرابر سودمند & برابر ابر & & \\
\hline $\begin{array}{l}q / \uparrow \wedge \\
(\tau / r \Lambda)\end{array}$ & $\begin{array}{l}\Delta / F T \\
(T / R T)\end{array}$ & $\begin{array}{l}\mid 9 / \% \Lambda \\
(\% / .9)\end{array}$ & $\begin{array}{l}\Delta / \Lambda T \\
(r / F r)\end{array}$ & $\begin{array}{l}\Delta / \wedge r \\
(1 / / 9)\end{array}$ & $\begin{array}{l}\mid 1 / \cdot r \\
(T / r \mid)\end{array}$ & انحراف معيانگين & $\mathbf{F z}$ \\
\hline $\begin{array}{l}-\cdot|r| \\
(\tau / \cdot \Lambda)\end{array}$ & $\begin{array}{l}9 / \pi r \\
(r / r q)\end{array}$ & $\begin{array}{l}\Delta / \Delta F \\
(F / q 1)\end{array}$ & $\begin{array}{l}-1 / 4 T \\
(1 / A Y)\end{array}$ & $\begin{array}{l}. / .9 \\
(T / 19)\end{array}$ & $\begin{array}{l}r / T r \\
(\tau / / r)\end{array}$ & انحراف معيار & Fcz \\
\hline
\end{tabular}

جدول r. ميانكَين و انحر اف استاندارد طول موج P300 در كانال هاى مغزى Pz

\begin{tabular}{|c|c|c|c|c|c|c|c|}
\hline \multicolumn{2}{|c|}{ گروه غيرخودى } & \multicolumn{4}{|c|}{ گروه خودى } & \multirow{2}{*}{ شاخص } & \multirow{2}{*}{ كانال } \\
\hline نابر ابر ناسودمند & نابرابر سودمند & برابر & نابرابر ناسودمند & نابرابر سودمند & برابر & & \\
\hline $\begin{array}{l}r / \cdot 1 \\
(\mathcal{E} / \mathcal{F})\end{array}$ & $\begin{array}{l}F / \Lambda \cdot \\
(r / 9 \cdot)\end{array}$ & 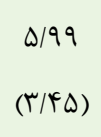 & $\begin{array}{l}F / \cdot F \\
(Y / \varphi \Delta)\end{array}$ & $\begin{array}{l}9 / 0 \cdot \\
(1 / 9 \wedge)\end{array}$ & $\begin{array}{l}r / T \Delta \\
(r / \Delta \cdot)\end{array}$ & انحراف ميانگين & $\mathbf{C z}$ \\
\hline $\begin{array}{l}r / 19 \\
(1 / \wedge 9)\end{array}$ & $\begin{array}{l}\Delta / r \Delta \\
(r / T \Delta)\end{array}$ & $\begin{array}{l}r / r \Lambda \\
(r / V \Delta)\end{array}$ & $\begin{array}{l}9 / 19 \\
(T / K \wedge)\end{array}$ & $\begin{array}{l}\text { T/YA } \\
(Y / Y I)\end{array}$ & $\begin{array}{l}r / 1 q \\
(\varepsilon / 4 \varphi)\end{array}$ & انحيانگين & $\mathbf{P z}$ \\
\hline
\end{tabular}

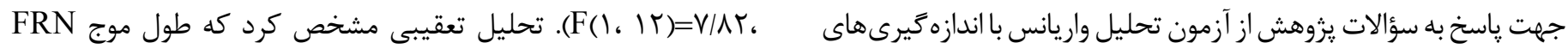

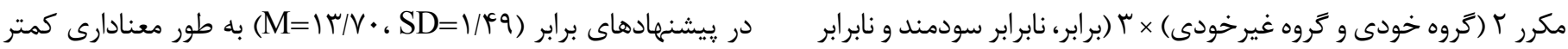

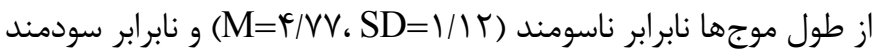

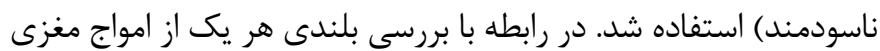

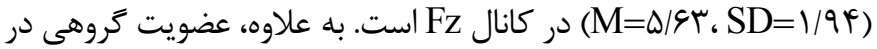

طول موج FRN در كانال Fz تفاوتى ايجاد نكرد (نمودار ץ). همجنين تعامل نوع يُيشنهادو عضويت گروهى در طول موج FRN در كانال Fz تفاوت معنادارى ايجاد كرده است. آزمون تعقيبى اثرات ساده نشان داد، موج FRN

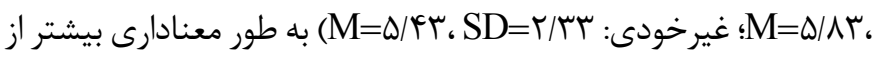

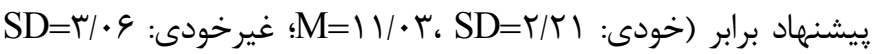

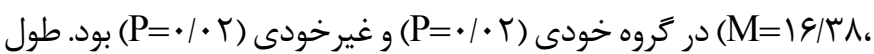

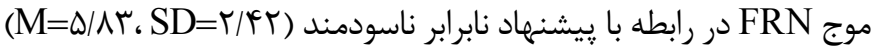

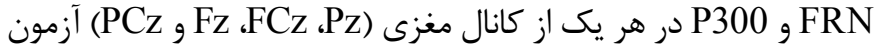
تحليل واريانس با اندازميرى مكرر جداگانه انجام شد. آزمون كرويت موجلى فرض همكنى واريانس را از طريق فرض كرويت تأييد كرد. همجنين آزمون لوين نشان داد كه واريانس بين كروهها در متغير وابسته

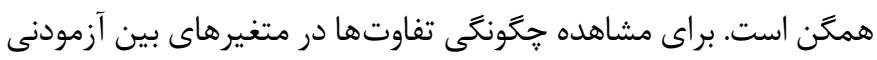
از آزمون تعقيبى بونفرونى تعديل شده استفاده شد.

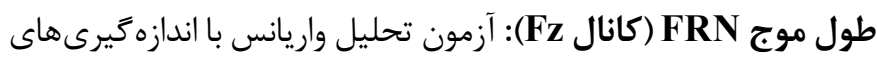

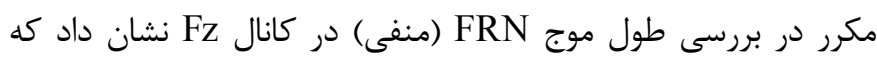

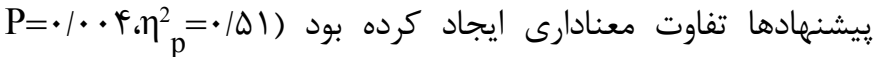



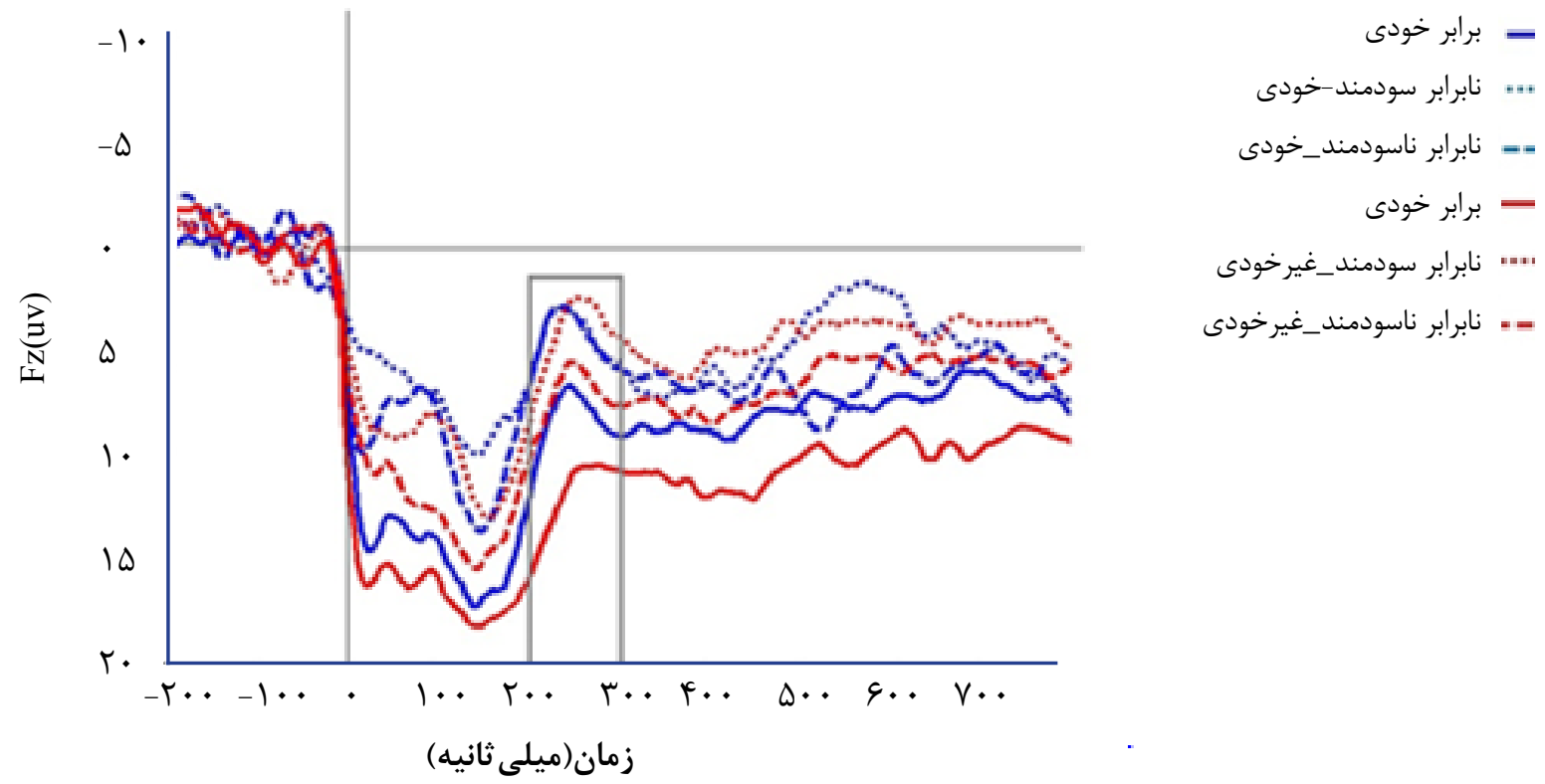

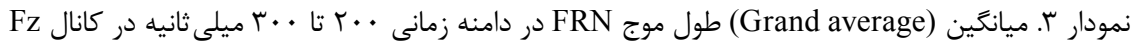

اندازهخيرى هاى مكرر در بررسى طول موج FRN در كانال Fcz نشان داد كه انواع ييشنهادها تفاوت معنادارى در طول موج FRN در كانال ايجاد كرده است (FcZ

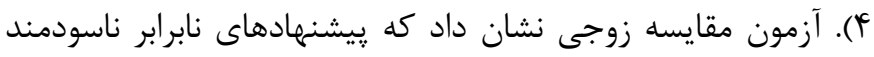

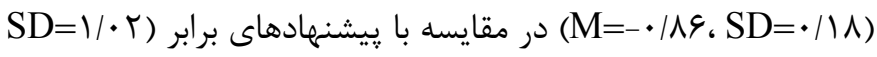

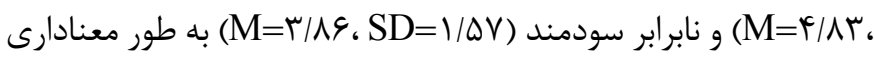

نيز به طور معنادارى بيشتر از يِشنهاد برابر (

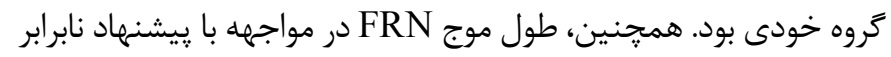

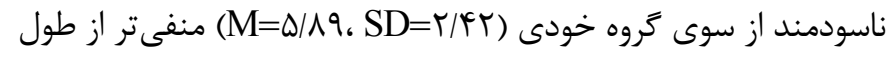

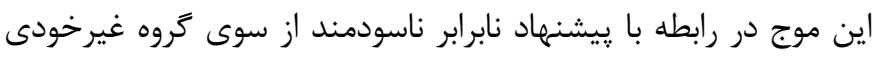

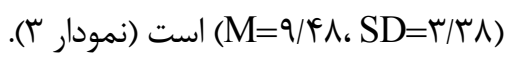
طول موج FRN (كانال Fcz): آزمون تحليل واريانس (ندار)
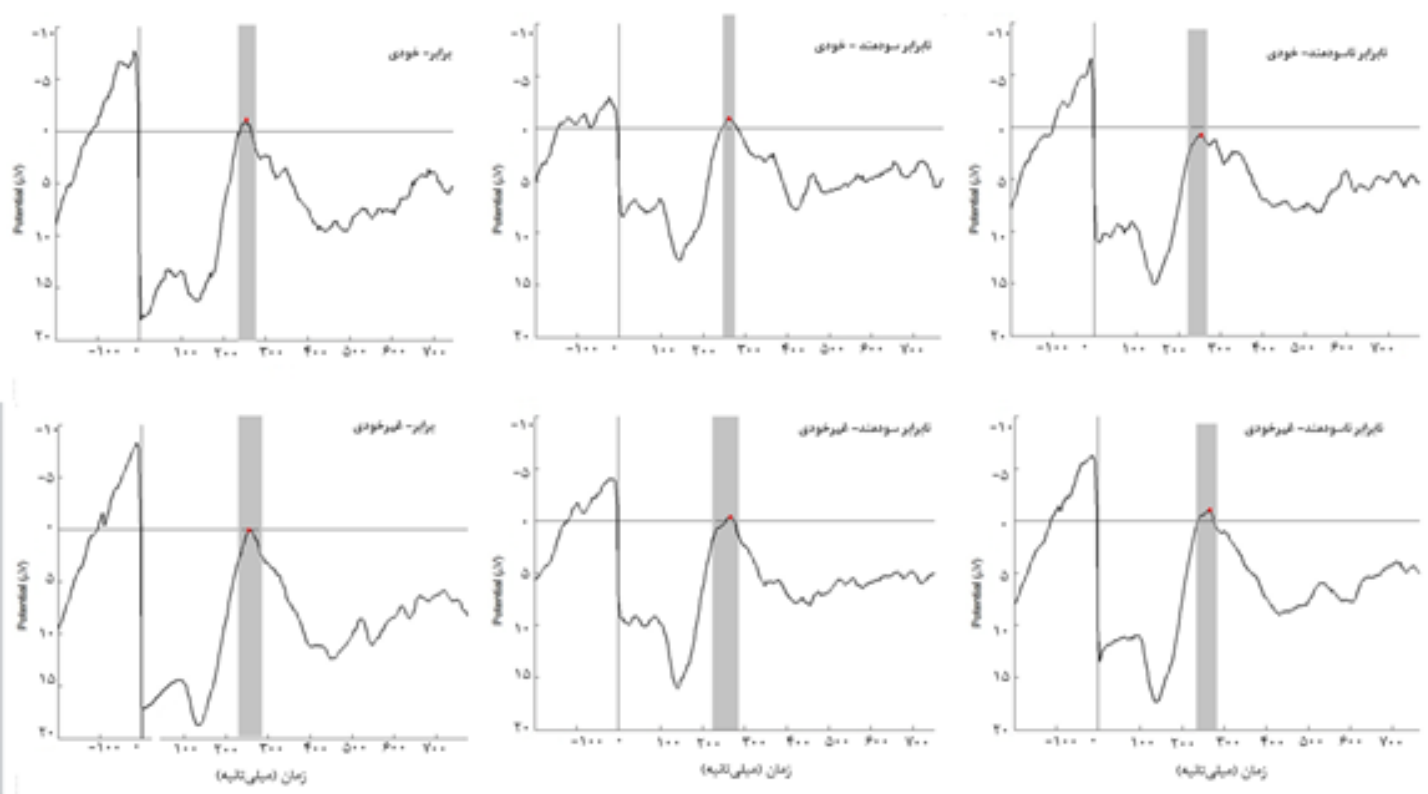

نمودار F. طول موج مؤلفه FRN در كانال Fz براى يك فرد شركت كننده 
گروه خودى (M=•/9r، SD=1/11) بيشتر از موج ايجاد شده در رابطه با ييشنمهادهاى ارائه شده توسط فرد گروه غيرخودى (9)

(M=r/Ar، به علاوه، تعامل نوع ريشنهاد و عضويت گروهى در طول موج FRN در
طول موج بيشترى ايجاد مى كنند. همجنين يافته ها نشان داد عضويت گروهى در طول موج FRN در كانال Fcz تفاوت معنادارى (FR )

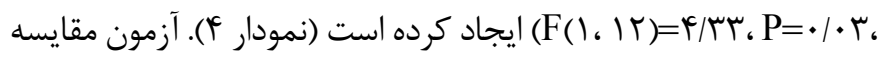
زوجى نشان داد كه موج FRN ايجاد شده در مواجهه با بيشنهادهاى
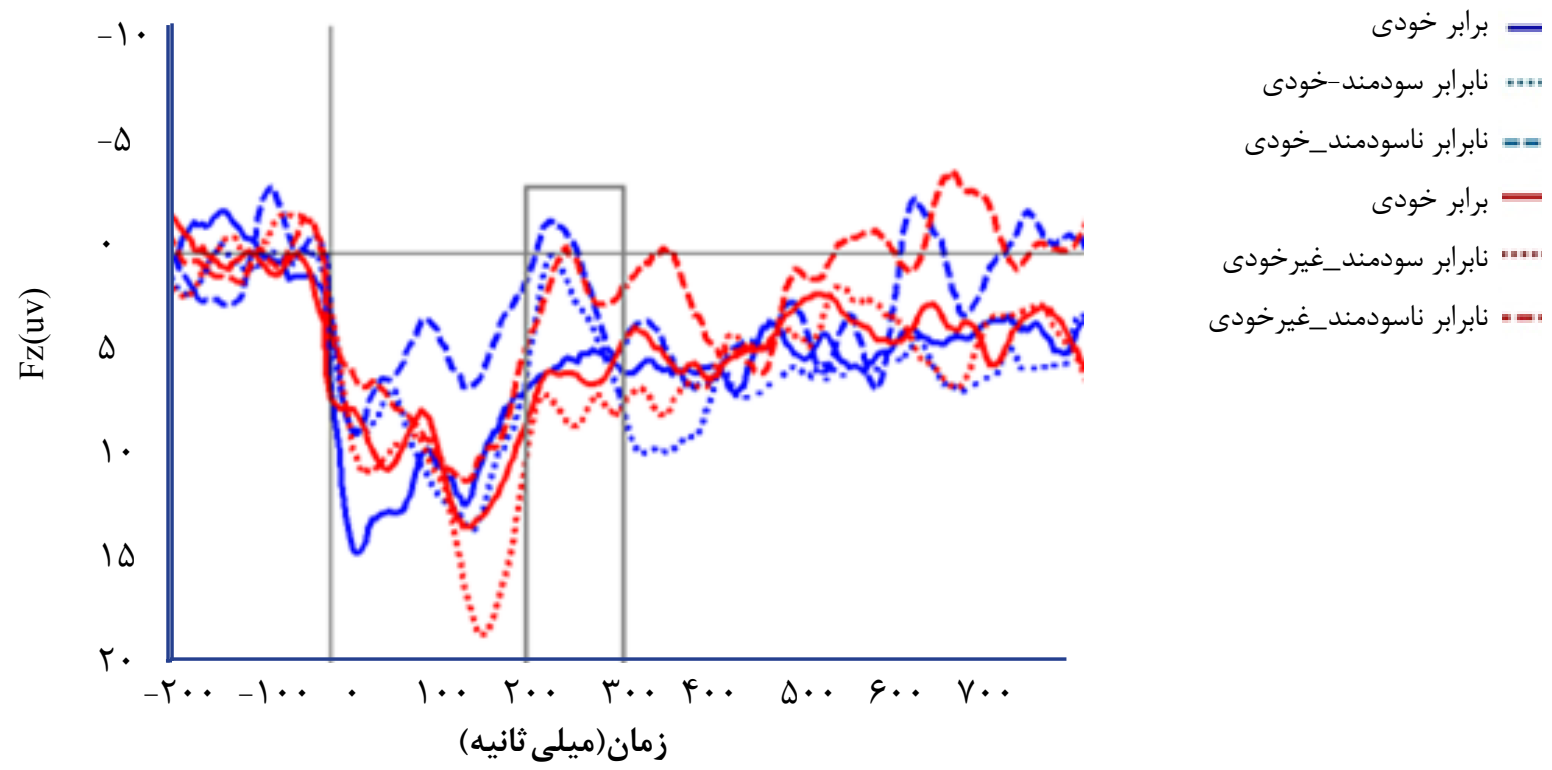

نمودار ه. ميانخين (Grand average) طول موج FRN در دامنه زمانى . تا . .ب ميلى ثانيه در كانال Fcz
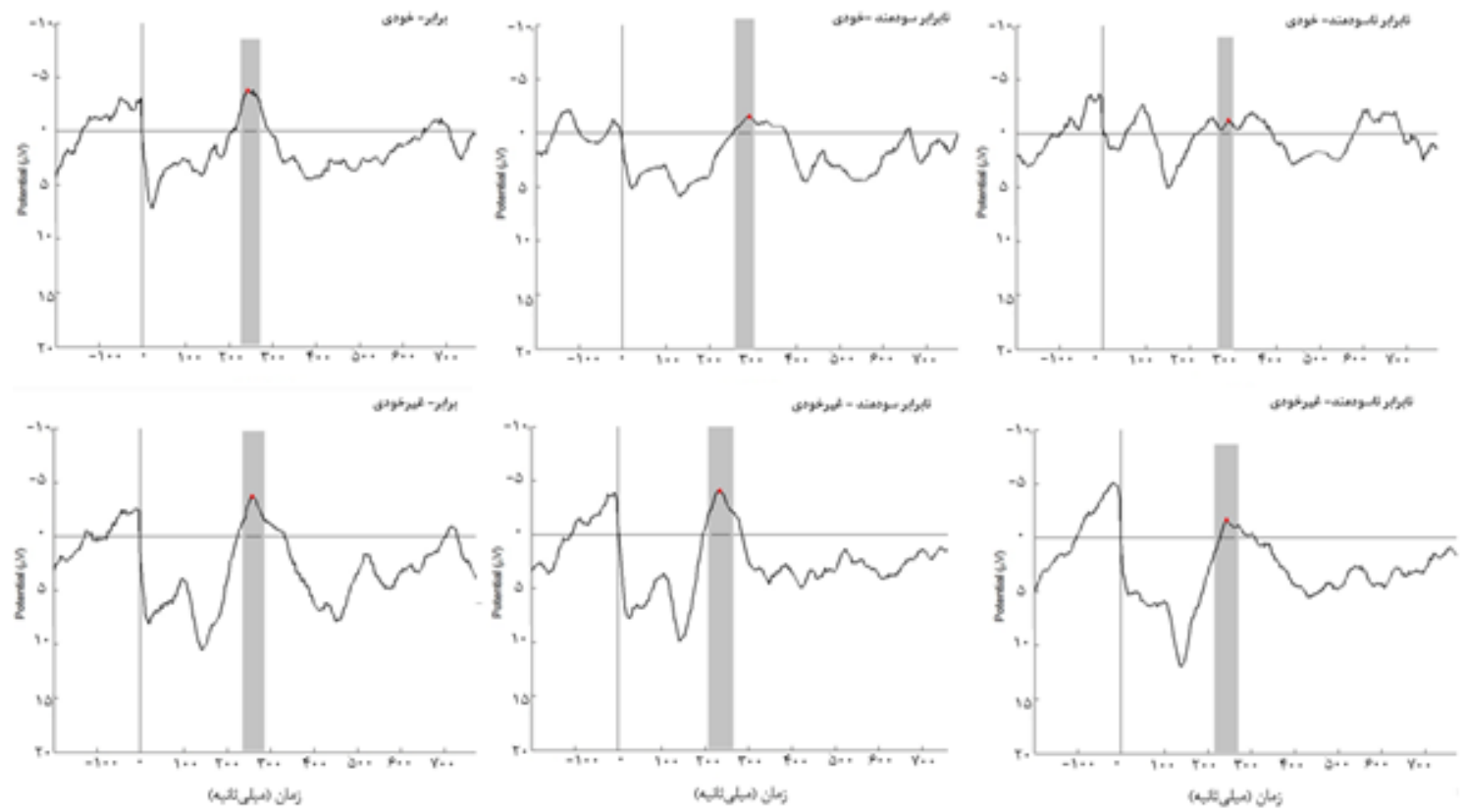

نمودار و. طول موج مؤلفه FRN در كانال Fcz براى يك فرد شركت كننده 
(M=Q/\& r به طور معنادارى بيشتر از هنگامى است كه شركت كننده با

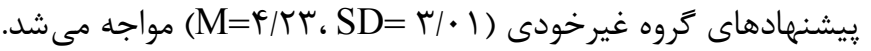
تعامل نوع يیشنهاد و عضويت گروهى در طول موج P300 در كانال

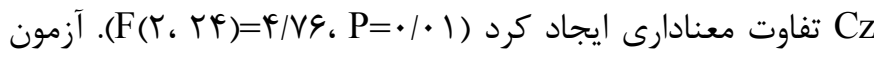

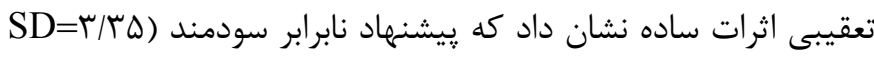

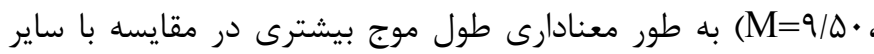

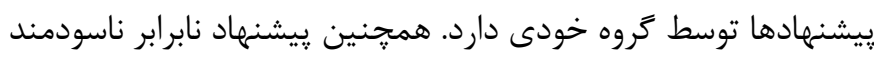

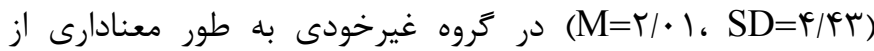

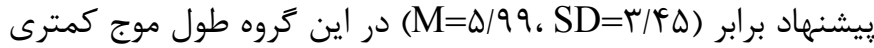
دارد. طول موج P300 به هنغام קيشنهاد نابرابر سودمند توسط كروه

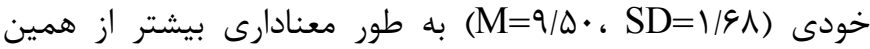

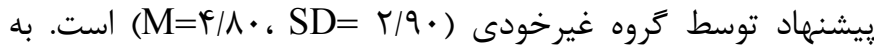

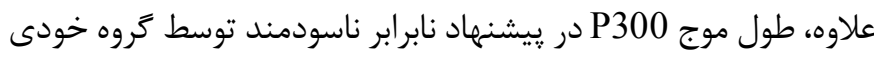
(M= Y / F، SD=Y/\&D) هن

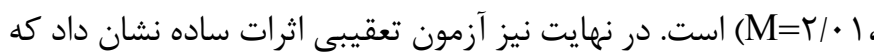

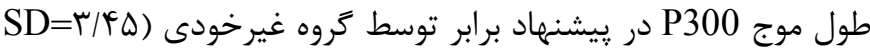
(M=Q/99، بيشتر از طول اين موج در موقعيت مشابه در رابطه با كروه

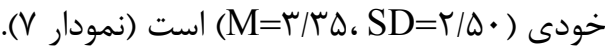
طول موج P300 (كانال Pz): آزمون تحليل واريانس با اندازه كيرىهاى (V) مكرر در بررسى طول موج P300 در كانال Pz نشان داد كه نوع

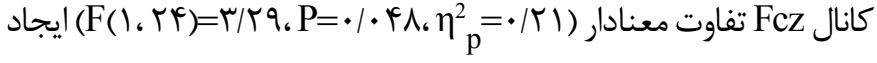
كرد. تحليل تعقيبى اثرات ساده نشان داد كه بين طول موج يِيشنهاد

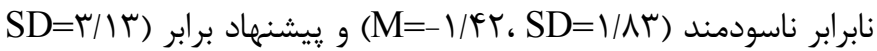

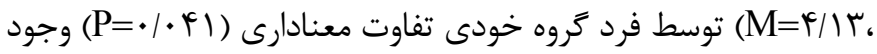

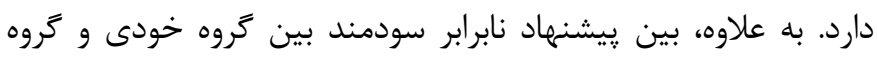

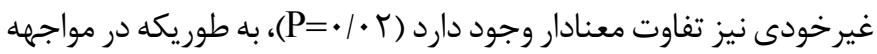

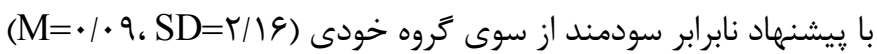

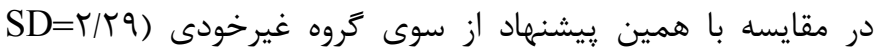
(M=E/ موج FRN، بلندترى در كانال Fcz بروز مى يابد.

طول موج P300 (كانال Cz): آزمون تحليل واريانس بال

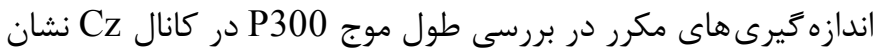
داد كه نوع پيشنهاد در طول اين موج در كانال Cz تفاوت معنادارى

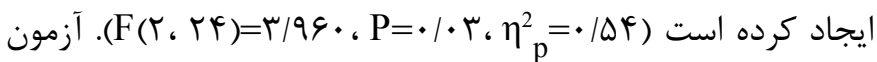
تعقيبى بونفرونى نشان داد طول موج يِيشنهاد نابرابر ناسودمند

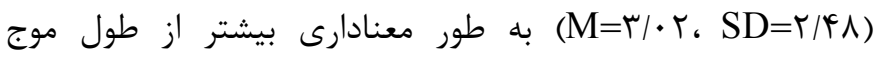

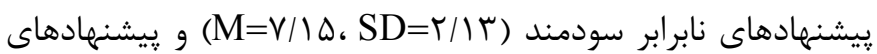

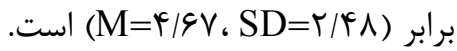
افزون بر اين، عضويت گروهى در طول موج P300 در كانال Cz تفاوت

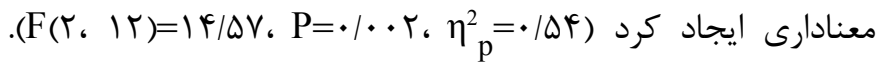
آزمون مقايسه زوجى نشان داد كه طول موج P300 در كانال Cz در المرال

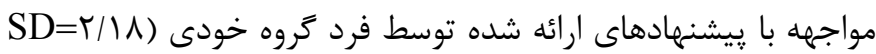
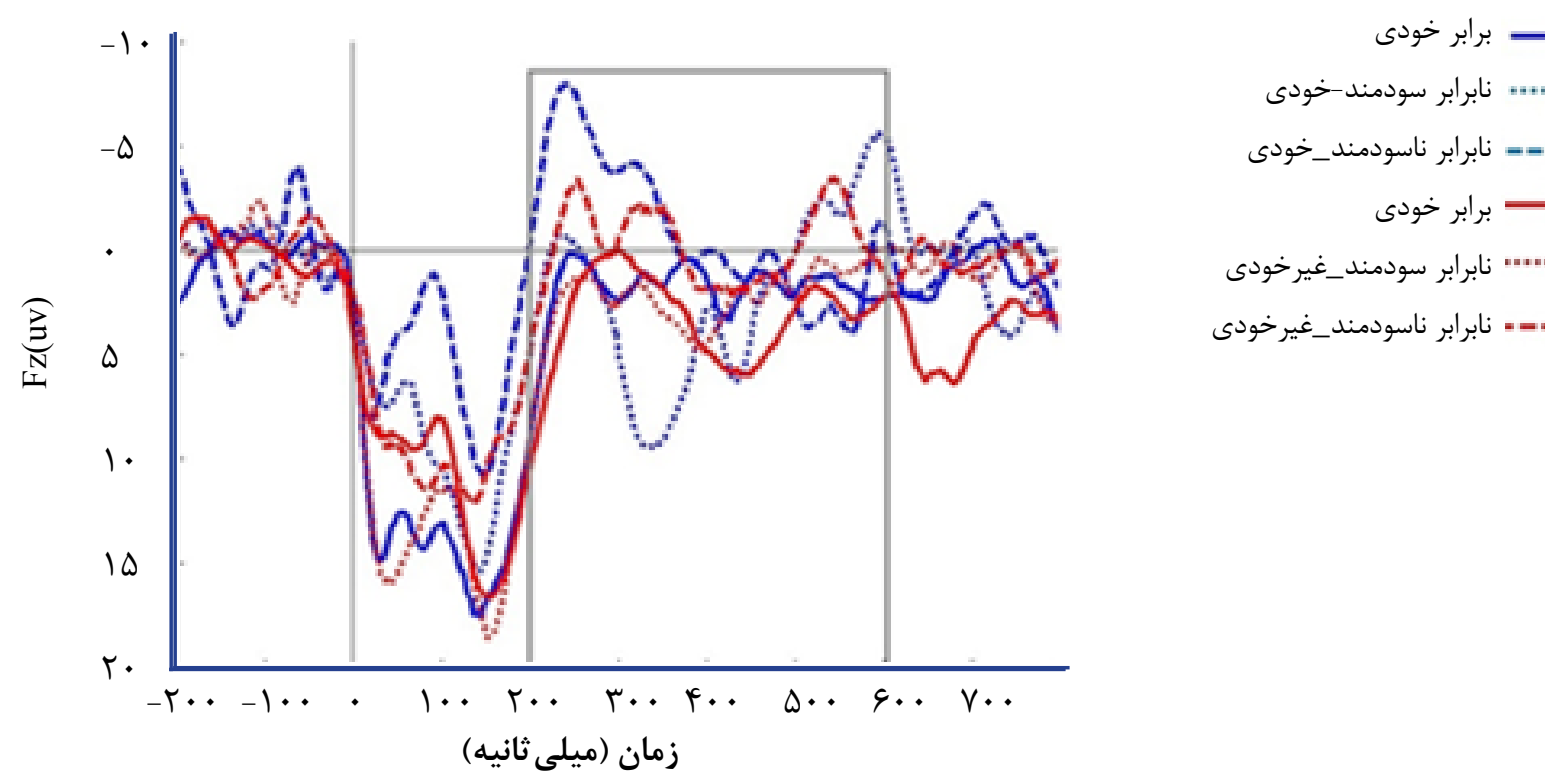

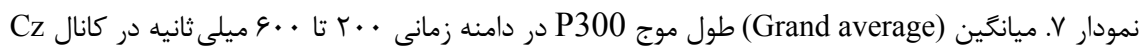



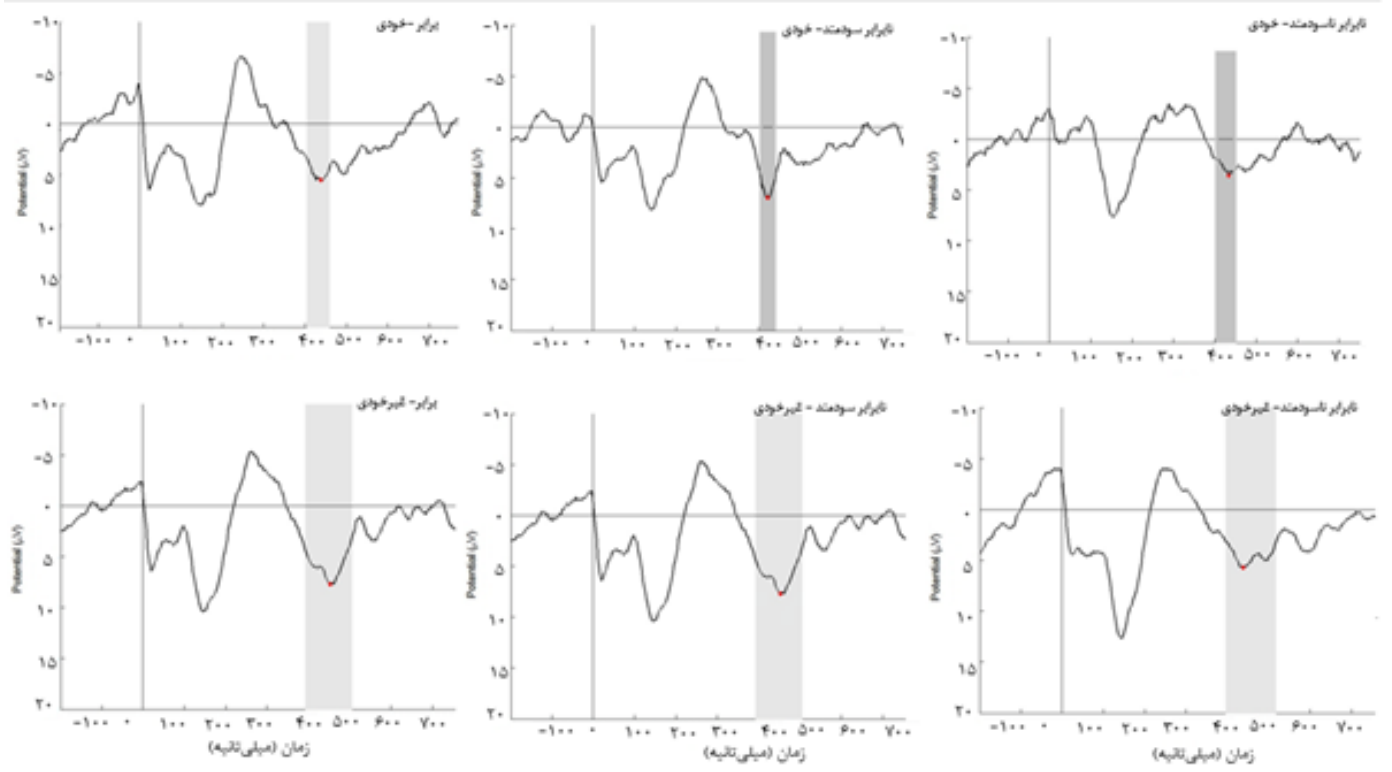

نمودار ^. طول موج مؤلفه P300 در كانال Cz براى يك فرد شركت كننده

P300 بيشترين طول موج را به هنكام مواجهه فرد با يِيشنهاد نابرابر ناسودمند از سوى كروه خودى در مقايسه با دو بيشنهاد ديخر داشته است. همينطور، اين موج در رابطه با بيشنهادهاى ارائه شده توسط كروه غيرخودى، بيشترين طول را در رابطه با پيشنهاد نابرابر سودمند

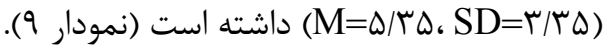

ييشنهاد در طول اين موج در كانال Pz تفاوت معنادارى ايجاد نكرده

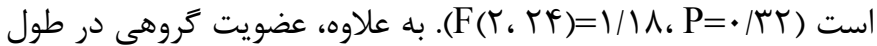

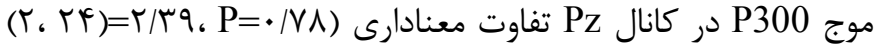
F ايجاد نكرد. اما تعامل نوع قيشنهاد و عضويت گروهى در طول اين

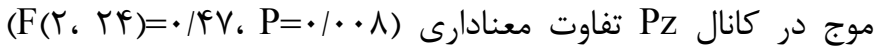

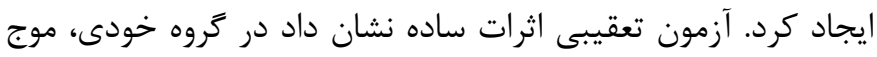
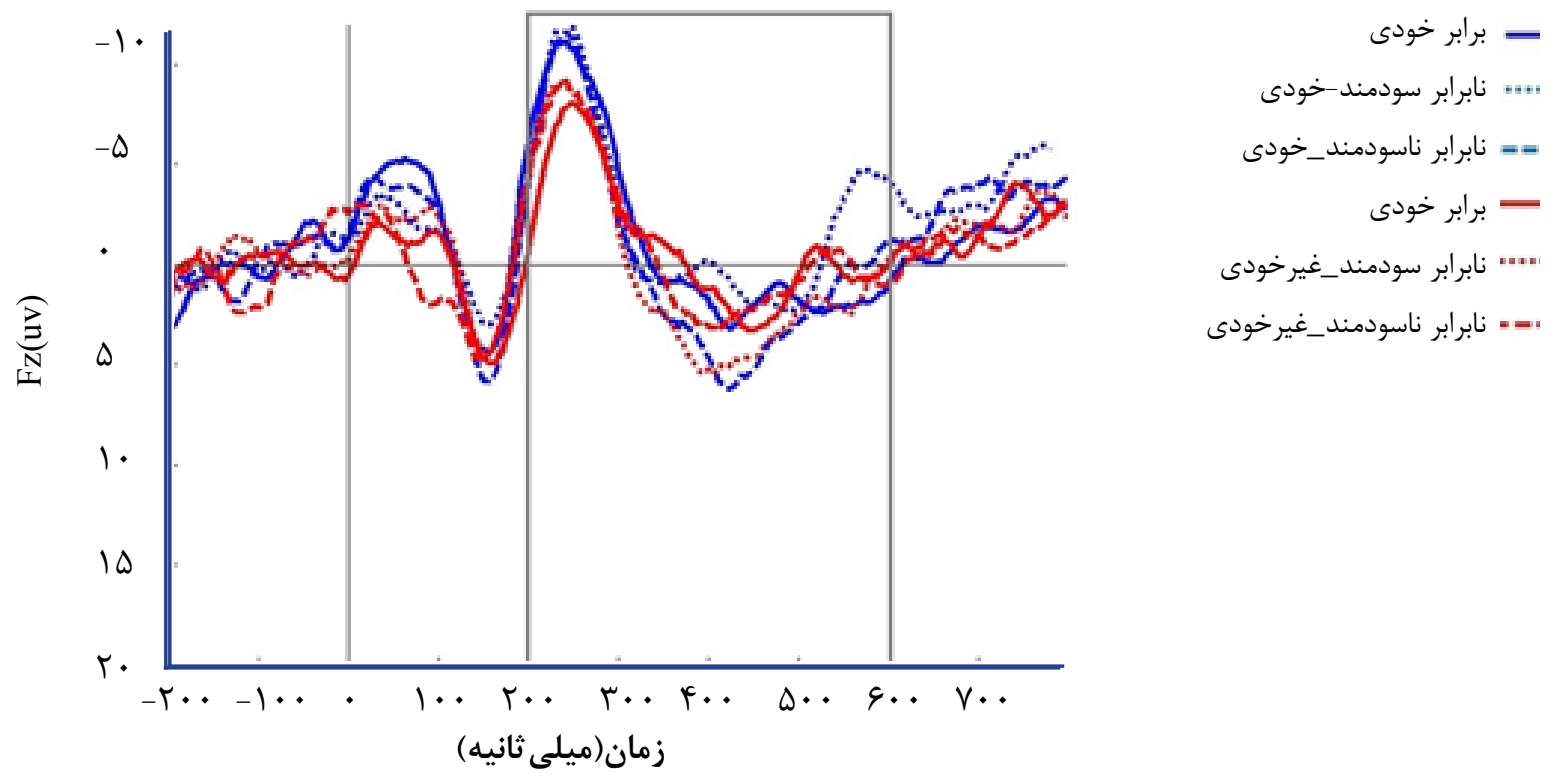

Pz نمودار 9. 

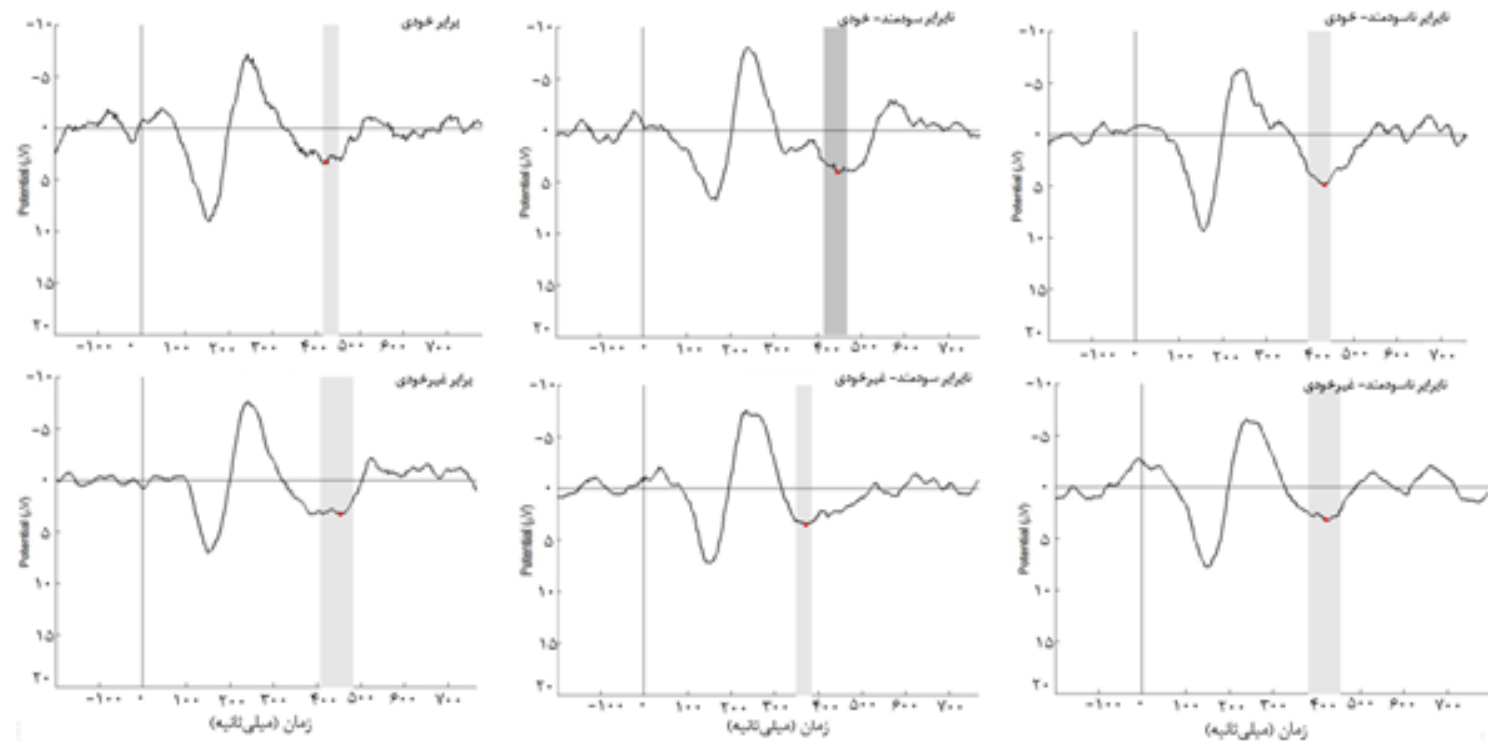

نمودار • 1. طول موج مؤلفه P300 در كانال Pz براى يك فرد شركت كننده

آن را نيذيرد (ץ). فرض ديگر اين است كه اجتناب از نابرابرى ناسودمند در افرادى كه احساس رقابت بيشترى دارند زودتر بروز مى يابد (9). به اين ترتيب، مطالعه حاضر با يافته هاى قبلى كه نشان

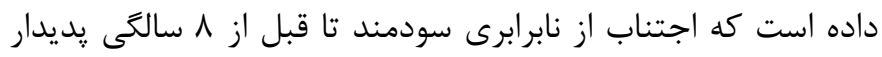

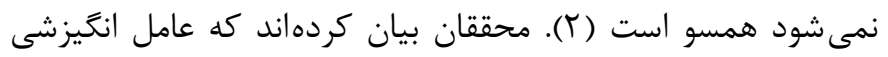

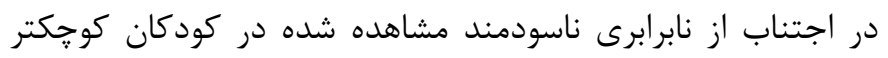

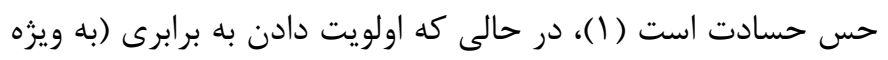

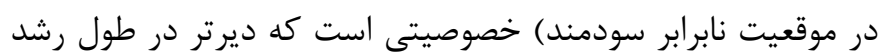
بروز مى يابد و با درونى شدن هنجارهاى اجتماعى مرتبط است (Y). كودكان مطالعه حاضر بِيشنهادهاى بيشترى از سوى كروه خودى را קذيرفتند. اين يافته با مطالعات ديخر كه نشان دادهاند كودكان افراد كروه خودى را در به اشتراگذارى و رفتارهاى تخصيص منابع باءئ

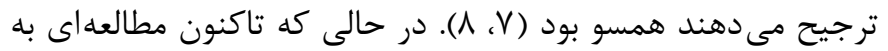

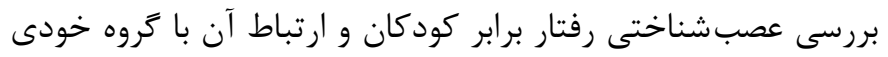

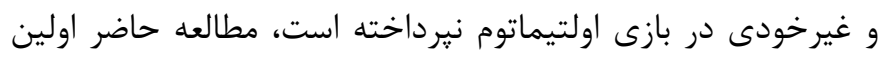

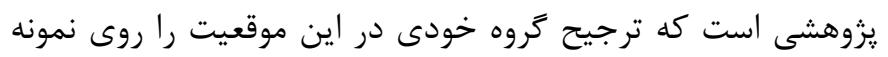
كودكان، به تصوير كشيده است. در اين مطالعه همجنين به بررسى امواج مغزى مرتبط با فرايندهاى هيجانى زودهنگام (FRN) و نيز فرايندهاى شناختى ديرهنگام

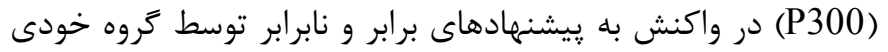

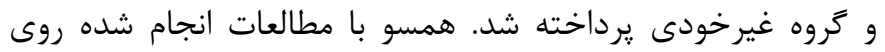

در مطالعه حاضر همبستهاى عصبشناختى اجتناب از نابرابرى كودكان 9 ساله در موقعيتهاى برابر، نابرابر سودمند و نابرابر ناسودمند

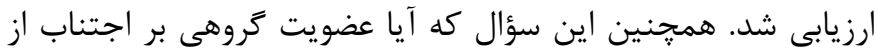

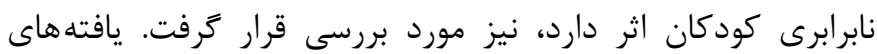
رفتارى اين مطالعه همخوان با ساير مطالعات انجام شده توسط تكليف

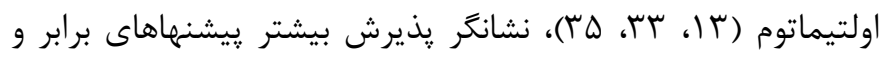

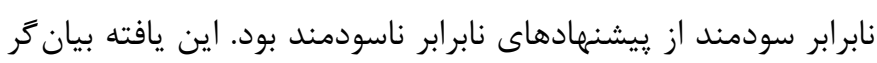

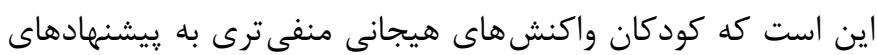
نابرابر داشتهاند. همجنين يذيرش معنادار يشنهادهاى نابرابر سودمند در مقايسه با پِيشنهادهاى نابرابر ناسودمند، نشان مى دهد كودكان مطالعه حاضر، تمايل ندارند كه براى برقرارى عدالت بهاى شخصى بيردازند. به اين معنا كه از دريافت ميزان بيشترى از منابع

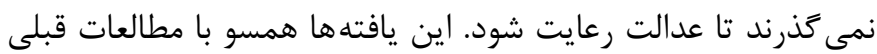

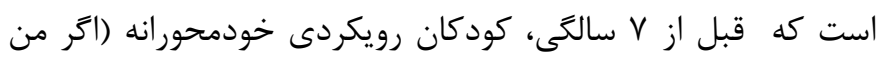

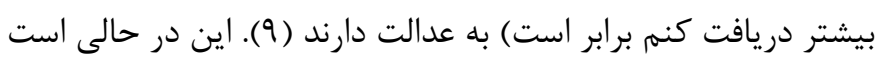

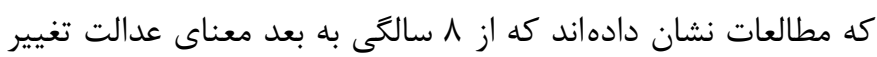
كرده و كودى به اين باور مىرسد كه اتر هر دو نفر برابر دريافت كنند، برابر است. محققان بر اين باورند كه بروز مقدم اجتناب از نابرابرى ناسودمند در مقايسه با اجتناب از نابر ابرى سودمند به وجود عدم برابرى در ارتباط با خود كودى مرتبط است. به كونهاى كه در اين موقعيت كودى خود را مورد رفتار نابرابر ديده و مى خواهد 
توسط او، با عدم پذيرش ييشنهادش، او را تنبيه مى كنند (9 (؟). اين يافته برخلاف يافته هاى قبلى است كه نشان دادند اجتناب از نابرابرى

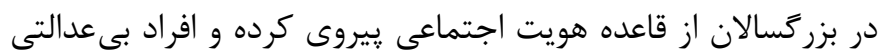

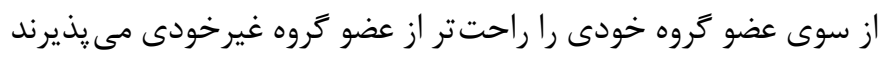

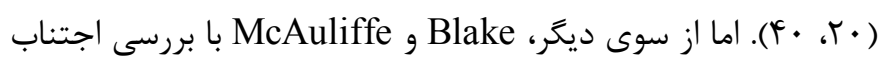

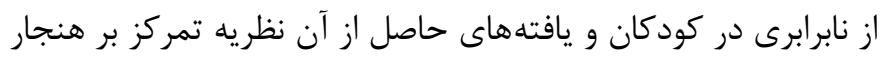
را ارائه كردند (ऍ). بنابراين، تفاوت بين يافته مطالعه حاضر و يافته هاى يِيشن ممكن است به كروه سنى مرتبط باشد. مى توان نتايج مطالعه حاضر را به مكانيزم يادگيرى اجتماعى مرتبط ساخت. بر اين اساس، كودكان به علائم بى عدالتى بسيار زودهنگام واكنش داده و بر اساس به

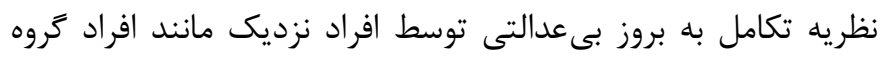

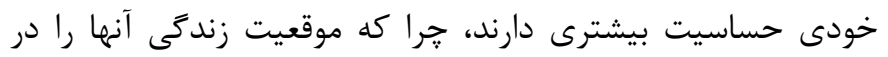

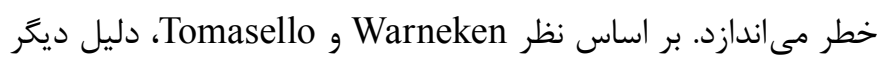

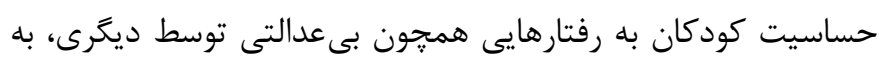

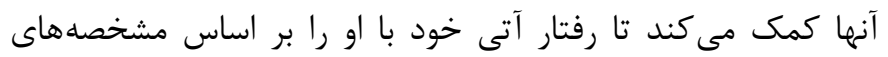
شخصيتى او تنظيم كنند ( أl). در عين حال، بزر كسالان به عنوان افراد تكامل و رشد يافته در جهت حفظ و تحكيم تروه خودى از اقدامات

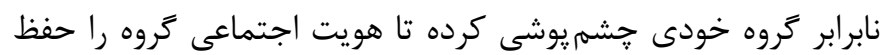
كنند. افزون بر اين، موضوع هويت اجتماعى و حفظ كروه خودى مفهومى است كه براى كودكان در بازه سنى زير 1 سال كه همجنان دغدغه هونه

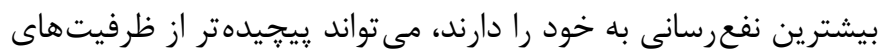

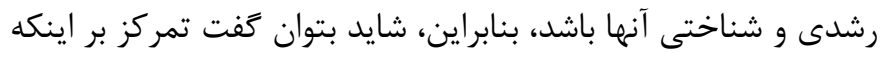

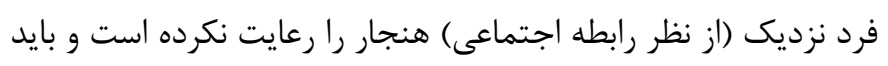

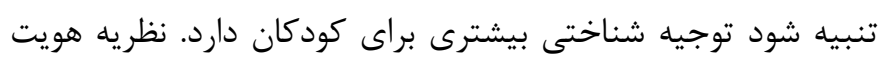

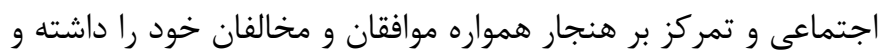
به نظر مى رسد جهت بررسى دقيقتر وجود تغييرات رشدى از تمركز بر هنجار به سوى هويت اجتماعى، لازم است كه مطالعات بعدى به بررسى ديى درى

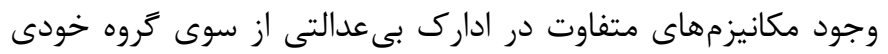
توسط كودكان و بزر گسالان بيردازند.

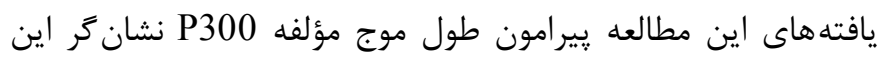

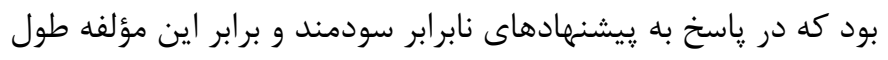

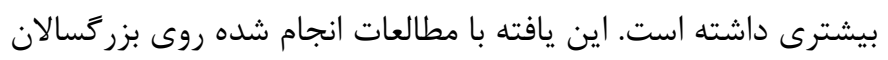

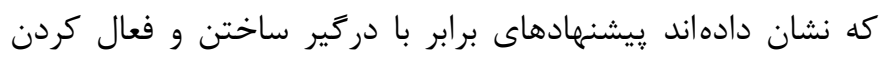

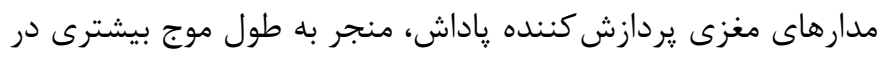

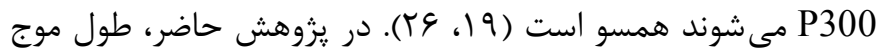

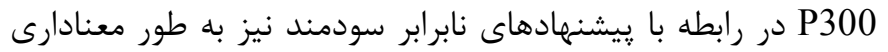
بالا بود. مىتوان اين يافته را نيز به مفهوم برابرى در حدود سن 4
بزركالان (•r) نتايج اين يزوهش نشانكر اين بود كه امواج مغزى

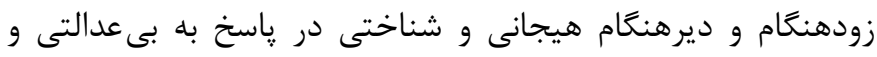
عدالت ادارك شده توسط كودكان اين مطالعه قابل شناسايى است.

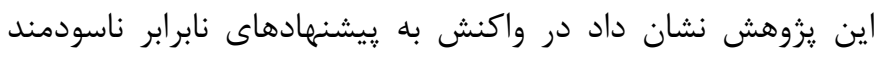

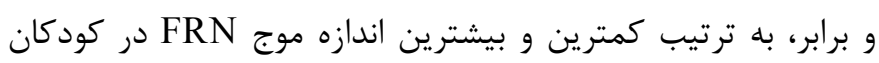

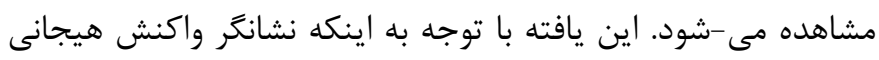

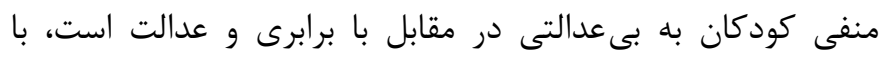

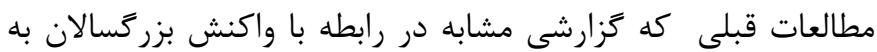
عدالت و بى عدالتى داشتند همسو است (9 19، • ب).

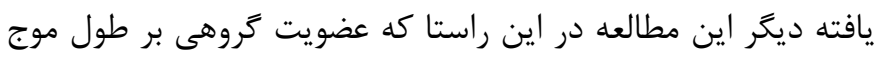

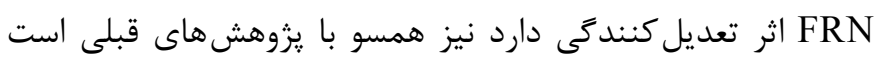

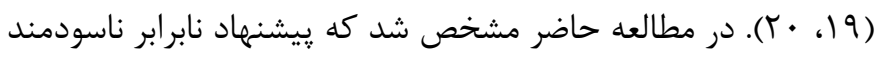

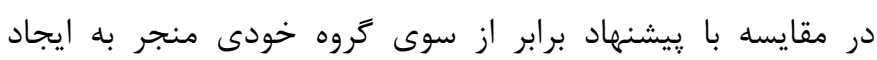

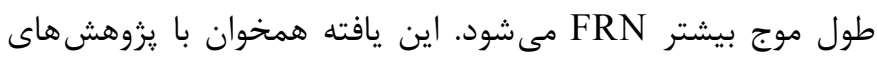

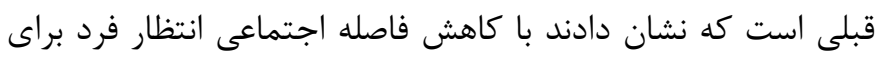

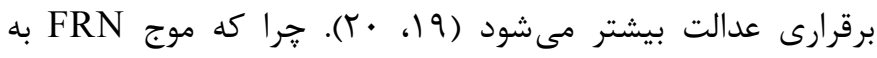
انتظار فرد از نابهنجارى حساس بوده و به هنكام بروز رويدادهايى كه مطابق با انتظار او نيستند طول موج بيشترى پيدا مى كند (ع).

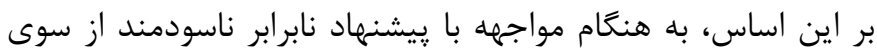

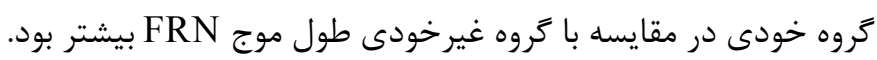

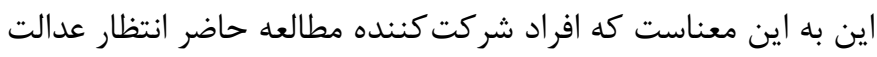

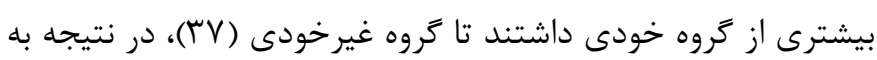

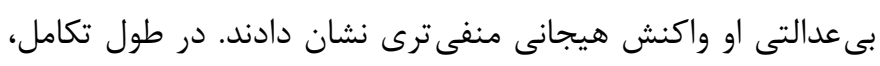

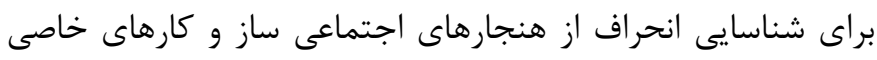

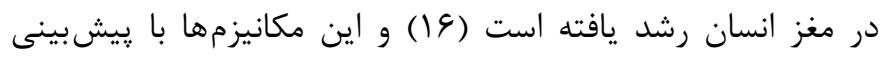

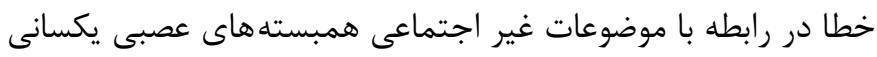

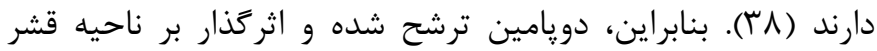

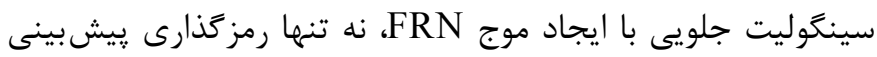
عدم مطابقت با انتظار در رابطه با پاداش مالى را نشان مى دهد، بلكه بيان كر عدم رعايت هنجار مورد انتظار نيز هست.

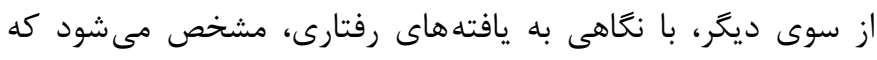

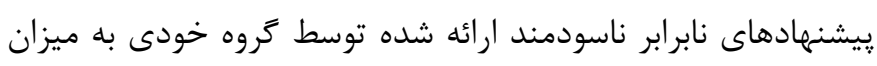

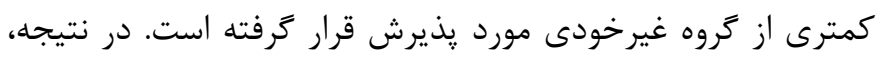
ممكن است بتوان اين كَونه نتيجه كَيرى كرد كه اجتناب از نابرابرى در رابطه با عضويت كروهى در مطالعه حاضر از نظريه تمركز بر هنجار

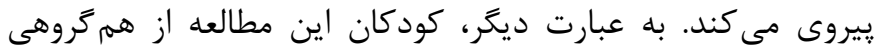
خود انتظار عدالت بيشترى داشته و در صورت عدم برقرارى عدالت 
بيشترى را مورد مطالعه قرار دهند.

\section{نتيجمه كيرى}

يزوهش حاضر اولين مطالعهاى بود كه به بررسى عدالت در زمينه تخصيص منابع در كودكان \& سال و ارتباط آن با عضويت گروهى از نظر عصبشناختى يرداخته است. يافتهها نشان گر اين بود كه كودكان مطالعه حاضر بر عدالت خودمحور باور داشته و هنوز به عدالت به معناى برابرى دست نيافتهاند. به علاوه، در اين گروه سنى در ياسخ به پيشنهادهاى برابر و نابرابر امواج مغزى FRN و نيز يديدار گشته و طول موج زودهنگام و خودكار هيجانى P300 و ديرهنگام و ارزيابى كننده شناختى (PRN) كروهى اثر رذيرفت. يافته هاى مطالعه حاضر همجنين نشان داد كه عضويت گروهى بر طول موج FRN و P300 اثر حذار است. در نهايت، يافتهاى اين مطالعه در راستاى نظريه تمركز بر هنجار بيان زر اين بود كه كودكان با رد رفتار نابرابر فرد گروه خودى او را بيشتر از فرد

$$
\text { گروه غيرخودى تنبيه مى كنند. }
$$

\section{تشكر و قدرواذى}

محققان اين يزوهش از شركت كنندكان در مطالعه، آزمايشگاه عصب شناختى يزوهشكده علوم شناختى و مغز دانشگاه شهيد بهشتى كمال تشكر را دارند. اين يزوهش بخشى از رساله دكترى فاطمه كشورى بوده است.

\section{References}

1. Shaw A, Olson KR. Children discard a resource to avoid inequity. Journal of Experimental Psychology: General. 2012;141(2):382-395.

2. Smith CE, Blake PR, Harris PL. I should but I won't: Why young children endorse norms of fair sharing but do not follow them. PloS one. 2013;8(3):e59510.

3. Blake PR, McAuliffe K. "I had so much it didn't seem fair": Eight-year-olds reject two forms of inequity. Cognition. $2011 ; 120(2): 215-224$.

4. Brosnan SF, De Waal FB. Evolution of responses to (un) fairness. Science. 2014;346(6207):1251776.

5. Fehr E, Schmidt KM. A theory of fairness, competition, and
سالغى مرتبط ساخت. به اين ترتيب كه در اين دوره زمانى، عدالت خودمحورانه بر تفكر كودى حاكم بوده و دريافت تعداد بيشترى از منابع در برابر فرد ديخر را تا حدى قابل يذيرش و نيز پاداش دهنده

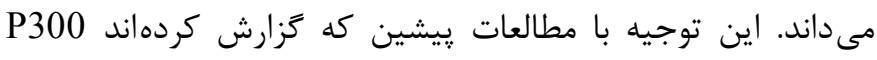

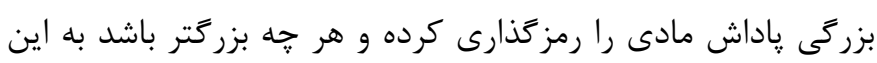
معناى ياداش بيشتر است، همسو است (Tr). مطالعه حاضر همجنين آشكار ساخت كه عضويت گروهى اثرى تعديل كننده بر طول موج P300 دارد. به طورى كه ييشنهادهاى ارائه شده توسط فرد زروه خودى و نيز ييشنهادهاى برابر و نابرابر سودمند توسط گروه خودى

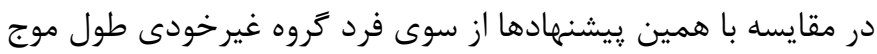
P300 بيشترى ايجاد مى كند. اين يافته با مطالعه Wu و همكاران

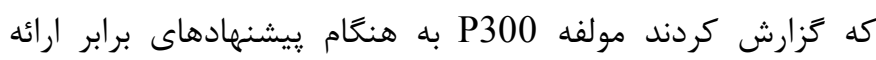
شده توسط فرد گروه خودى طول موج بيشترى دارد همسو است (9 (1). اين مطالعه داراى محدوديتهايى بود از جمله اينكه: يزوهش حاضر تنها روى كودكان \& ساله ساكن تهران انجام شده و از نظر تعميميذيرى لزوماً به تمام كودكان اين گروه سنى در ايران ممكن تهن است قابل تعميم نباشد. يافته هاى اين مطالعه نشان گر اين بود كه عدم اجتناب از برابرى در رابطه با ٍيشنهادهاى نابرابر سودمند در سنين بالاتر بروز مى يابد. ريشنهاد مى شود براى مشاهده وجود يا عدم وجود اين حساسيت در گروه كودكان، مطالعات بعدى به بررسى اين گروه سنى بيردازند. همجنين حجم نمونه كم محدوديت ديخر يزوهش حاضر بود، ييشنهاد مى شود يزوهشهاى بير بعدى تعداد نمونه

cooperation. The quarterly Journal of Economics. 1999 Aug $1 ; 114(3): 817-868$.

6. Dawes CT, Fowler JH, Johnson T, McElreath R, Smirnov O. Egalitarian motives in humans. Nature. 2007;446(7137):794-796. 7. Loewenstein GF, Thompson L, Bazerman MH. Social utility and decision making in interpersonal contexts. Journal of Personality and Social Psychology. 1989;57(3):426-441.

8. Güroğlu B, Will GJ, Crone EA. Neural correlates of advantageous and disadvantageous inequity in sharing decisions. PloS one. 2014;9(9):e107996.

9. Blake PR, McAuliffe K, Corbit J, Callaghan TC, Barry O, Bowie A, et al. The ontogeny of fairness in seven societies. 
Nature. 2015;528(7581):258-261.

10. Kanngiesser P, Warneken F. Young children consider merit when sharing resources with others. PloS one. 2012;7(8):e43979.

11. Baumard N, Mascaro O, Chevallier C. Preschoolers are able to take merit into account when distributing goods. Developmental Psychology. 2012;48(2):492-498.

12. McAuliffe K, Dunham Y. Group bias in cooperative norm enforcement. Philosophical Transactions of the Royal Society B: Biological Sciences. 2016 ;371(1686):20150073.

13. Sanfey AG, Rilling JK, Aronson JA, Nystrom LE, Cohen JD. The neural basis of economic decision-making in the ultimatum game. Science. 2003;300(5626):1755-1758.

14. Tabibnia G, Satpute AB, Lieberman MD. The sunny side of fairness: preference for fairness activates reward circuitry (and disregarding unfairness activates self-control circuitry). Psychological Science. 2008;19(4):339-347.

15. Van't Wout M, Kahn RS, Sanfey AG, Aleman A. Affective state and decision-making in the ultimatum game. Experimental Brain Research. 2006;169(4):564-568.

16. Montague PR, Lohrenz T. To detect and correct: Norm violations and their enforcement. Neuron. 2007;56(1):14-18.

17. Güroğlu B, Van Den Bos W, Rombouts SA, Crone EA. Unfair? It depends: neural correlates of fairness in social context. Social Cognitive and Affective Neuroscience. 2010;5(4):414-423.

18. Campanha C, Minati L, Fregni F, Boggio PS. Responding to unfair offers made by a friend: Neuroelectrical activity changes in the anterior medial prefrontal cortex. Journal of Neuroscience. 2011;31(43):15569-15574.

19. Wu Y, Leliveld MC, Zhou X. Social distance modulates recipient's fairness consideration in the dictator game: An ERP study. Biological Psychology. 2011;88(2-3):253-262.

20. Wang Y, Zhang Z, Bai L, Lin C, Osinsky R, Hewig J. Ingroup/outgroup membership modulates fairness consideration: Neural signatures from ERPs and EEG oscillations. Scientific Reports. 2017;7:39827.

21. Polezzi D, Daum I, Rubaltelli E, Lotto L, Civai C, Sar- tori $\mathrm{G}$, et al. Mentalizing in economic decision-making. Behavioural Brain Research. 2008;190(2):218-223.

22. Yeung N, Sanfey AG. Independent coding of reward magnitude and valence in the human brain. Journal of Neuroscience. 2004;24(28):6258-6264.

23. Boksem MA, De Cremer D. Fairness concerns predict medial frontal negativity amplitude in ultimatum bargaining. Social Neuroscience. 2010;5(1):118-128.

24. Hewig J, Kretschmer N, Trippe RH, Hecht H, Coles MG, Holroyd CB, et al. Hypersensitivity to reward in problem gamblers. Biological Psychiatry. 2010;67(8):781-783.

25. Yu R, Hu P, Zhang P. Social distance and anonymity modulate fairness consideration: An ERP study. Scientific Reports. 2015;5:13452.

26. Hajcak G, Holroyd CB, Moser JS, Simons RF. Brain potentials associated with expected and unexpected good and bad outcomes. Psychophysiology. 2005;42(2):161-170.

27. Gehring WJ, Willoughby AR. The medial frontal cortex and the rapid processing of monetary gains and losses. Science. 2002;295(5563):2279-2282.

28. Goyer JP, Woldorff MG, Huettel SA. Rapid electrophysiological brain responses are influenced by both valence and magnitude of monetary rewards. Journal of Cognitive Neuroscience. 2008;20(11):2058-2069.

29. Fukushima H, Hiraki K. Perceiving an opponent's loss: Gender-related differences in the medial-frontal negativity. Social Cognitive and Affective Neuroscience. 2006;1(2):149-157.

30. Fukushima H, Hiraki K. Whose loss is it? Human electrophysiological correlates of non-self reward processing. Social Neuroscience. 2009;4(3):261-275.

31. Donchin E, Coles MG. Is the P300 component a manifestation of context updating?. Behavioral and Brain Sciences. 1988;11(3):357-374.

32. Paulus M. Children's inequity aversion depends on culture: A cross-cultural comparison. Journal of Experimental Child Psychology. 2015;132:240-246.

33. Güth W, Schmittberger R, Schwarze B. An experimental 
analysis of ultimatum bargaining. Journal of Economic Behavior \& Organization. 1982;3(4):367-388.

34. Tajfel H. Intergroup behavior. Introducing Social Psychology. New York:Penguin Books;1978. pp. 401-466.

35. Yamagishi T, Horita Y, Takagishi H, Shinada M, Tanida S, Cook KS. The private rejection of unfair offers and emotional commitment. Proceedings of the National Academy of Sciences. 2009;106(28):11520-11523.

36. Fehr E, Glätzle-Rützler D, Sutter M. The development of egalitarianism, altruism, spite and parochialism in childhood and adolescence. European Economic Review. 2013;64:369-383.

37. Bellebaum C, Polezzi D, Daum I. It is less than you expected: the feedback-related negativity reflects violations of reward mag- nitude expectations. Neuropsychologia. 2010;48(11):3343-3350.

38. Shapiro SP. The social control of impersonal trust. American Journal of Sociology. 1987;93(3):623-658.

39. Harris LT, Fiske ST. Neural regions that underlie reinforcement learning are also active for social expectancy violations. Social Neuroscience. 2010;5(1):76-91.

40. Brüne M, Tas C, Wischniewski J, Welpinghus A, Heinisch C, Newen A. Hypnotic ingroup-outgroup suggestion influences economic decision-making in an Ultimatum Game. Consciousness and Cognition. 2012;21(2):939-946.

41. Warneken F, Tomasello M. The emergence of contingent reciprocity in young children. Journal of Experimental Child Psychology. 2013;116(2):338-350. 